\title{
Review \\ Critical Roles of Lysophospholipid Receptors in Activation of Neuroglia and Their Neuroinflammatory Responses
}

\author{
Bhakta Prasad Gaire and Ji-Woong Choi * \\ College of Pharmacy and Gachon Institute of Pharmaceutical Sciences, Gachon University, Yeonsu-gu, \\ Incheon 21936, Korea; samarpanbp@gmail.com \\ * Correspondence: pharmchoi@gachon.ac.kr; Tel.: +82-32-820-4955
}

Citation: Gaire, B.P.; Choi, J.-W. Critical Roles of Lysophospholipid Receptors in Activation of Neuroglia and Their Neuroinflammatory Responses. Int. J. Mol. Sci. 2021, 22 7864. https://doi.org/10.3390/ ijms22157864

Academic Editor: Dong-Soon Im

Received: 17 June 2021

Accepted: 21 July 2021

Published: 23 July 2021

Publisher's Note: MDPI stays neutral with regard to jurisdictional claims in published maps and institutional affiliations.

Copyright: (c) 2021 by the authors. Licensee MDPI, Basel, Switzerland. This article is an open access article distributed under the terms and conditions of the Creative Commons Attribution (CC BY) license (https:// creativecommons.org/licenses/by/ $4.0 /)$.

\begin{abstract}
Activation of microglia and/or astrocytes often releases proinflammatory molecules as critical pathogenic mediators that can promote neuroinflammation and secondary brain damages in diverse diseases of the central nervous system (CNS). Therefore, controlling the activation of glial cells and their neuroinflammatory responses has been considered as a potential therapeutic strategy for treating neuroinflammatory diseases. Recently, receptor-mediated lysophospholipid signaling, sphingosine 1-phosphate (S1P) receptor- and lysophosphatidic acid (LPA) receptor-mediated signaling in particular, has drawn scientific interest because of its critical roles in pathogenies of diverse neurological diseases such as neuropathic pain, systemic sclerosis, spinal cord injury, multiple sclerosis, cerebral ischemia, traumatic brain injury, hypoxia, hydrocephalus, and neuropsychiatric disorders. Activation of microglia and/or astrocytes is a common pathogenic event shared by most of these CNS disorders, indicating that lysophospholipid receptors could influence glial activation. In fact, many studies have reported that several S1P and LPA receptors can influence glial activation during the pathogenesis of cerebral ischemia and multiple sclerosis. This review aims to provide a comprehensive framework about the roles of S1P and LPA receptors in the activation of microglia and/or astrocytes and their neuroinflammatory responses in CNS diseases.
\end{abstract}

Keywords: lysophospholipid receptors; S1P; LPA; microglia; astrocyte; neuroinflammation

\section{Introduction}

Glial cells are non-neuronal central nervous system (CNS)-resident cells that support neurons for CNS homeostasis and normal neuronal functioning in a healthy condition [1]. Abundantly distributed in the CNS, glial cells are in continuous communication with neurons, immune cells, and blood vessels [2,3]. They are primarily divided into four phenotypes, namely, astrocytes, oligodendrocytes, microglia, and ependymal cells [1]. Ependymal cells are present at the lining of the ventricular system. Their roles during CNS injury remain unclear. Oligodendrocytes are myelin-producing cells that play important roles in myelin-degenerating diseases such as multiple sclerosis (MS), neuromyelitis optica, and idiopathic inflammatory demyelinating diseases [4]. Microglia and astrocytes are considered major glial cell types that are critical regulators of brain injury and recovery in diverse neuroinflammatory disorders. Microglia are innate immune cells of the CNS that play important roles in the host defense [5,6]. Astrocytes are in close proximity to neurons and blood vasculatures [7]. Both microglia and astrocytes are the most motile and active glial cells in the CNS. They can sense any changes in the CNS milieu through their processes. Therefore, microglia and astrocytes are the primary cells to be activated upon any hazardous stimuli [8,9]. Activation of microglia and astrocytes in acute CNS injuries is necessary for the host defense [10]. For instance, activated microglia are involved in brain cleaning system as they can remove dead cells and tissue debris [11], whereas activated astrocytes can prevent neurodegeneration through the formation of glial scar [12]. However, chronic activation of microglia and astrocytes are considered as detrimental 
because these activated cells can promote neuroinflammatory events and ultimately lead to neurodegeneration [13].

Bioactive lysophospholipids and their receptors (lysophospholipid receptors) are believed to be potential targets for drug design to treat various diseases, which ensures the possibility for an entirely new class of lipidomic-based therapeutic agents $[14,15]$. Originally, lysophospholipids were thought to be precursors and metabolites in the biosynthesis of membrane phospholipids [16-18]. Later, two of them, lysophosphatidic acid (LPA) and sphingosine 1-phosphate (S1P), were identified as important extracellular signaling molecules that could participate in various biological functions in organisms, including immunity, inflammation, muscle contraction, development, fibrosis, obesity, cancer, angiogenesis, cellular migration, and neurite extension [17,19-21]. Being extracellular signaling molecules, LPA and S1P can signal through binding to and activating at least 11 cognate G protein-coupled receptors (six LPA receptors, $\mathrm{LPA}_{1}-\mathrm{LPA}_{6}$ and five S1P receptors, $\mathrm{S}_{1} \mathrm{P}_{1}$ $\mathrm{S} \mathrm{P}_{5}$ ) and mediate a variety of biological functions throughout the body [22-24]. LPA and S1P are abundantly present in the CNS, where receptor-mediated LPA and S1P signaling are believed to play crucial roles in neurological disorders involving neuroinflammation, the major cause of neurodegeneration [25-28]. In fact, LPA and S1P receptors have emerged as novel and fascinating therapeutic targets for several inflammatory CNS diseases, including MS, neuropathic pain, spinal cord injury, cerebral ischemia, traumatic brain injury, hydrocephalus, fetal hypoxia, seizure, hearing loss, Sandhoff disease, and neuropsychiatric disorders $[17,20]$. In most of these CNS diseases, neuroinflammatory responses initiated by activated microglia and astrocytes are considered major neuroharmful events. In fact, previous studies have revealed that these neuroglial cells express most LPA and S1P receptors [29-33]. Therefore, LPA and S1P receptors can influence glial cell biology, including activation, proliferation, migration, etc. In addition, LPA and S1P receptors can regulate inflammatory responses of microglia and astrocytes, consequently signifying that these receptors are potential drug targets for treating various neuroinflammatory disorders. The aim of this review is to explore the roles of receptor-mediated LPA and S1P signaling in neuroinflammation through the regulation of responses of microglia and astrocytes.

\section{S1P Receptors in Activation of Microglia and Their Neuroinflammatory Responses}

A growing body of evidence has revealed the involvement of S1P receptors in microglial biology in diverse neuroinflammatory disorders. For example, it has been suggested that S1P might be involved in the migration and morphological alteration of microglia [34,35]. In cultured microglia, S1P can influence ATP release via volume-regulated anion channels [35]. The released ATP is associated with the migration of microglia [35]. S1P lyase-deficient microglia, in which amounts of S1P are found to be increased, show a significant decrease in ramification index of microglia (a morphological phenotype indicating microglial activation), along with increased ionized calcium-binding adapter molecule 1 (Iba1) reactivity [34], suggesting that S1P can promote microglial activation. In addition, mRNA and protein expression levels of proinflammatory mediators (such as tumor necrosis factor- $\alpha$ (TNF- $\alpha$ ) and interleukin-6 (IL-6)) and mRNA expression levels of Toll-like receptor 4 (TLR4) are significantly increased in S1P lyase-deficient microglia [34], demonstrating that increased S1P levels are associated with microglial activation and their proinflammatory responses. In mice brains, microinjection of S1P into the corpus callosum can dramatically increase microglial activation, as evidenced by an increased number of Iba1-positive cells [27]. Such an S1P-induced microglial activation is closely associated with increased brain damage upon induction of transient middle cerebral artery occlusion (tMCAO), a type of focal cerebral ischemia [27]. Similarly, in microglia subjected to oxygen-glucose deprivation/re-oxygenation (OGD/R), a popular in vitro model of cerebral ischemia [36,37], S1P exposure can increase the production of IL-17A, which is associated with neuronal apoptosis [38]. Besides S1P itself, sphingosine kinase 1 (SphK1), a principal kinase responsible for S1P production in the brain [39], is also a key regulator of microglial activation and subsequent production of inflammatory mediators [40]. Protein 
expression levels of SphK1 are upregulated in lipopolysaccharide (LPS)-stimulated BV2 microglia cell line [40]. Suppression of SphK1 activity with either pharmacological or genetic tools can attenuate the upregulation of inflammatory mediators such as TNF- $\alpha$, IL-1 $\beta$, and inducible nitric oxide synthase (iNOS) [40], further indicating the role of S1P in neuroinflammatory activation of microglia.

The involvement of S1P receptors in microglial activation and their inflammatory responses has been further validated through experimental studies employing FTY720 (fingolimod, Gilenya ${ }^{\circledR}$, Novartis, Switzerland), a drug to treat MS. FTY720 is a non-selective modulator of S1P receptors [41,42] with a pharmacological potential as a functional antagonist of $\mathrm{S}_{1} \mathrm{P}_{1}$ [43-45] and $\mathrm{S}_{3} \mathrm{P}_{3}$ [46]. It can decrease microglial activation in diverse CNS diseases, including Alzheimer's disease (AD), Parkinson's disease (PD), cerebral ischemia, and MS [47]. FTY720 can significantly attenuate mRNA and protein expression levels of proinflammatory cytokines such as TNF- $\alpha$, IL- $1 \beta$, and IL- 6 in LPS-stimulated mouse primary microglia [48]. In addition, it can decrease lysophosphatidylcholine-induced production of nitric oxide (NO), TNF- $\alpha$, and IL-1 $\beta$ from microglia [49]. In a kainic acidinduced neurodegenerative mouse model, FTY720 can significantly decrease the number of Iba1-positive cells in the brain and attenuate JNK phosphorylation in LPS-stimulated microglia [50]. In mice exposed to chronic unpredictable mild stress, FTY720 can decrease depressive-like behaviors by attenuating hippocampal NOD-like receptor pyrin domaincontaining protein 3 (NLRP3) inflammasome activation [51], which is believed to occur in microglia because microglia are central regulators of NLRP3 inflammasome activation in the brain [52]. FTY720 decreases mRNA expression levels of iNOS and CD16, but increases mRNA expression levels of arginase 1 (Arg-1) and CD206, suggesting that FTY720 can promote M2 polarization of activated microglia (anti-inflammatory/neuroprotective phenotype) while attenuating M1 polarization (proinflammatory/neuro-harmful phenotype) [51] FTY720 and SEW2871 (a selective agonist for $\mathrm{S1P}_{1}$ [53]) can significantly attenuate microglial activation in the substantia nigra of 1-methyl-4-phenyl-1,2,3,6-tetrahydropyridine (MPTP)-induced PD mouse [54], further indicating the role of S1P receptors in microglial biology. In an ischemic stroke-challenged brain, FTY720 can attenuate microglial activation and M1 polarization as evidenced by attenuated protein expression levels of Iba1, iNOS, and NLRP3 [55]. The effect of FTY720 on microglial polarization in cerebral ischemia is further confirmed in OGD/R-challenged microglia, in which FTY720 treatment decreases mRNA expression levels of M1 polarization markers such as CD86, cyclooxygenase-2 (COX-2), iNOS, IL-1 $\beta$, IL-6, TNF- $\alpha$, and interferon- $\gamma$ (IFN- $\gamma$ ), whereas it increases mRNA expression levels of $\mathrm{M} 2$ polarization markers and growth factors such as transforming growth factor- $\beta 1$ (TGF- $\beta 1$ ), TGF- $\beta 2$, TGF- $\beta 3$, C-C motif chemokine ligand 2 (CCL2), granulocyte colony-stimulating factor (GCSF), granulocyte-macrophage colony-stimulating factor (GMCSF), and insulin-like growth factor- $1 \alpha$ (IGF-1 $\alpha$ ) [55]. FTY720 can decrease mRNA expression levels of proinflammatory cytokines and chemokines such as IL-1 $\alpha$, IL-1 $\beta$, TNF$\alpha$, IL-6, CCL2, CCL3, CCL4, and CCL9 in LPS-stimulated primary microglial culture [56]. In addition, FTY720 treatment can significantly decrease the number of activated microglia at the proximity of beta-amyloid $(\mathrm{A} \beta)$ plaque in AD-prone transgenic mice [57]. Similarly, following a hypoxic/ischemic insult in mice, FTY720 treatment can attenuate microglial activation and upregulation of proinflammatory cytokines such as TNF- $\alpha$ and IL- $1 \beta$ at protein and mRNA expression levels in the white matter of the brain [58]. FTY720 can also attenuate microglial activation in twitcher mice as numbers of Iba1-positive cells and ameboid microglia in the white matter of the cerebellum are decreased after treatment with FTY720 [59,60]. Findings of these in vitro and in vivo studies suggest that FTY720 can promote the anti-inflammatory phenotype and reduce the proinflammatory phenotype of microglia.

Besides FTY720, a few other S1P receptor modulators can also influence microglial activation, further strengthening the notion that receptor-mediated S1P signaling plays an important role in the activation of microglia and their inflammatory responses. In the culture of corticostriatal slices obtained from mice with experimental autoimmune 
encephalomyelitis (EAE) as a popular animal model of MS [61,62], ozanimod (RPC1063, Zeposia ${ }^{\circledR}$, Bristol Myers Squibb), a recently developed drug to treat MS by targeting $\mathrm{S}_{1} \mathrm{P}_{1}$ and $\mathrm{S}_{1} \mathrm{P}_{5}$ [63], can attenuate $\mathrm{M} 1$ microglial activation, as evidenced by reduced mRNA expression levels of Iba1, iNOS, IL-1 $\beta$, and TNF- $\alpha$, while it induces M2 microglial activation, as evidenced by increased mRNA expression levels of Found in Inflammatory Zone 1 (FIZZ1) [63]. These ex vivo effects of ozanimod on M1 microglial activation were further validated in Th1 cytokines-stimulated BV2 microglia, in which ozanimod decreased mRNA expression levels of IL-6, Regulated upon Activation, Normal T Cell Expressed and Presumably Secreted (RANTES), and TNF- $\alpha$ [64]. Siponimod (BAF312, Mayzent ${ }^{\circledR}$, Novartis) is also a drug used to treat MS by targeting $\mathrm{S}_{1} \mathrm{P}_{1}$ and $\mathrm{S} \mathrm{P}_{5}$ [65]. It can dramatically attenuate microglia activation in the brains of EAE mice [66]. In addition, $\mathrm{RP}-001$, a selective agonist for $\mathrm{S}_{1} \mathrm{P}_{1}$ [67], can attenuate microglial activation in mice brains challenged with sub-arachnoid hemorrhage, as evidenced by a significant reduction in Iba1 immunoreactivity [68]. Besides cerebral ischemia and MS, receptor-mediated S1P signaling could also influence other neurodegenerative diseases. FTY720 administration can significantly reduce protein expression levels of proinflammatory mediators (COX-2 and TNF- $\alpha$ ) in the hippocampus of A $\beta$-induced AD-like Wistar rat [69]. FTY720 can also dramatically attenuate microglial activation in 5xFAD AD-like mice [57,70]. In addition, it can significantly decrease the number of ameboid microglia in $5 \times \mathrm{FAD}$ mice while there is no difference in the number of resting microglia upon FTY720 administration [57], further demonstrating that FTY720 can attenuate microglial activation in AD mice. Ameboid microglia are neurotoxic [71,72]. FTY720 can reduce neurotoxic microglia by attenuating inflammatory microglial activation in an AD mouse brain [57]. Similarly, in APP/PS1 mice, FTY720 administration can attenuate microglial activation, as evidenced by the suppressed Iba1 expression in the hippocampus and neocortex [73,74]. FTY720 can also attenuate microglial activation in experimental models of $\mathrm{PD}[75,76]$. It can attenuate the increase in the number of Iba1-immunopositive cells in the substantia nigra and striatum at 21 days after mice are exposed to 6-hydroxydopamine (6-OHDA) [75]. These studies clearly reflect the involvement of S1P receptors in microglia-mediated neuroinflammatory events during CNS pathogenesis. These aforementioned independent studies clearly indicate that S1P itself and its receptor can influence microglial activation, possibly leading to inflammatory responses in diverse neurodegenerative diseases. In the following sections, we will discuss how each S1P receptor can affect the activation of microglia and their neuroinflammatory responses.

Regulatory roles of $\mathrm{S1P}_{1}$ in the activation of microglia and their neuroinflammatory responses have been well demonstrated in cerebral ischemia and MS. In cerebral ischemia, $\mathrm{S}_{1} \mathrm{P}_{1}$ plays a pathogenic role with a close link to neuroinflammation, mainly by influencing microglial activation $[77,78]$. Suppressing $\mathrm{S}_{1} \mathrm{P}_{1}$ activity with the administration of AUY954, one of its functional antagonists [43], can reduce proinflammatory responses and enhance anti-inflammatory responses of activated microglia in post-ischemic brains [78]. Experimental studies employing an $\mathrm{S}_{1} \mathrm{P}_{1}$ knockdown approach also support these findings as $\mathrm{S1P}_{1}$ knockdown can reduce mRNA expression levels of proinflammatory cytokines in LPS-stimulated cultured microglia [77]. In fact, suppressing $\mathrm{S}_{1} \mathrm{P}_{1}$ activity with either AUY954 administration or $\mathrm{S1P}_{1}$ knockdown can attenuate brain damages after $\mathrm{tMCAO}$ challenge [77]. Such neuroprotection by AUY954 is closely associated with attenuation of microglial activation, proliferation, and morphological transformation into ameboid cells in the brains of mice challenged with $\mathrm{tMCAO}$ [77]. Furthermore, $\mathrm{S}^{\mathrm{P}} \mathrm{P}_{1}$ can regulate the activation of mitogen-activated protein kinases (MAPKs) and microglial NF- $\mathrm{kB}$ signaling pathways in post-ischemic brains [78]. Both MAPKs and NF- $\mathrm{kB}$ signaling pathways are associated with the regulation of neuroinflammation in cerebral ischemia [79-81]. In MS pathogenesis, modulation of $\mathrm{S}_{1} \mathrm{P}_{1}$, presumably inhibition, can lead to the attenuation of microglial activation [82-84]. FTY720 modulates microglial activation in the injured spinal cords of EAE mice, in which FTY720 administration dramatically attenuates mRNA upregulation of proinflammatory mediators, including C-X-C motif chemokine ligand 9 (CXCL9), 
CXCL11, CXCL13, CCL1, CCL2, CCL4, CCL5, CCL7, CCL17, Axl, FosB, Fos, and TNF- $\alpha$, while it increases the upregulation of colony-stimulating factor 2 (CSF2), Chi3l3, IL-10, IGF-1, Rentla, and CD206 [84]. In the corpus callosum of cuprizone-administered mouse, in another model of MS with a feature of demyelination [85,86], FTY720 administration can dramatically decrease the number of Iba1-immunopositive cells and upregulate mRNA expression levels of proinflammatory cytokines and chemokines [83]. These effects of FTY720 might be mediated through downregulation of $\mathrm{S1P}_{1}$ in the brain because FTY720 administration completely abolishes cuprizone-induced protein expression levels of $\mathrm{S}_{1} \mathrm{P}_{1}$ in the brain [83]. Such possible involvement of $\mathrm{S}_{1} \mathrm{P}_{1}$ has been reaffirmed with CYM5442, another $\mathrm{S}_{1} \mathrm{P}_{1}$ selective modulator and a functional antagonist of $\mathrm{S}_{1} \mathrm{P}_{1}$ [82], indicating that $\mathrm{S} 1 \mathrm{P}$ receptor modulation, possibly $\mathrm{S}_{1} \mathrm{P}_{1}$ modulation, could dramatically attenuate neuroinflammatory responses of microglia in MS.

$\mathrm{S} \mathrm{P}_{2}$ also plays a critical role in the activation of microglia and their inflammatory responses in post-ischemic brains [87]. JTE013, an antagonist for $\mathrm{S1P}_{2}[88,89]$, can dramatically attenuate microglial activation at day 1 and day 3 after ischemic challenge (tMCAO challenge) [87]. It can also attenuate microglial proliferation and mRNA upregulation of proinflammatory mediators in post-ischemic brains [87]. Importantly, JTE013 administration into $\mathrm{tMCAO}$-challenged mice can lead to the attenuation of NF- $\mathrm{KB}$ signaling in activated microglia, suggesting that suppression of $\mathrm{S}_{2} \mathrm{P}_{2}$ activity can attenuate transcriptional activation of proinflammatory mediators in post-ischemic brains [87]. The inhibition of inflammatory microglial activation upon pharmacological inhibition of $\mathrm{S1P}_{2}$ in a post-ischemic brain could be the associated neuroprotective mechanism achieved by either JTE013 administration or genetic deletion of $\mathrm{S1P}_{2}$ against $\mathrm{tMCAO}$ challenge $[87,90]$. JTE013 can also decrease mRNA expression levels of proinflammatory cytokines in BV2 murine microglia upon LPS stimulation [87], suggesting that $\mathrm{S} \mathrm{P}_{2}$ is a critical regulator of microglial activation. However, how $\mathrm{S}_{2} \mathrm{P}_{2}$ regulates microglial activation in other CNS pathologies remains unclear.

Roles of $\mathrm{S}_{1} \mathrm{P}_{3}$ in the activation of microglia and their proinflammatory responses have also been reported in cerebral ischemia. Blockade of $\mathrm{S1P}_{3}$ with CAY10444, a specific $\mathrm{S}_{3} \mathrm{P}_{3}$ antagonist [91-93], can decrease the number of Iba1-positive cells, microglial proliferation, morphological transformation into neurotoxic ameboid shape, and inflammatory M1 polarization of microglia [94]. In addition, $\mathrm{S} \mathrm{P}_{3}$ can influence the activation of microglial $\mathrm{NF}-\mathrm{KB}$ and the production of inflammatory cytokines in injured brains after an ischemic challenge [94]. In primary microglia, suppressing $\mathrm{S} \mathrm{P}_{3}$ activity with either CAY10444 or $\mathrm{S}_{1} \mathrm{P}_{3}$-specific shRNA lentivirus particles can dramatically attenuate mRNA upregulation of proinflammatory cytokines, suggesting that $\mathrm{S}_{1} \mathrm{P}_{3}$ is involved in the proinflammatory activation of microglia [94]. Unsurprisingly, $\mathrm{S} \mathrm{P}_{3}$ has been validated as a therapeutic target for drug development to treat cerebral ischemia because CAY10444 administration can attenuate brain damages such as brain infarction, neurological functional deficit, and neural cell death after $\mathrm{tMCAO}$ challenge [94]. However, the role of $\mathrm{S1P}_{3}$ in microglial activation-associated other CNS disorders is yet to be uncovered.

$\mathrm{S} \mathrm{P}_{4}$ is poorly expressed in the brain. Therefore, brain cells do not express $\mathrm{S} \mathrm{P}_{4}$ under normal conditions [95,96]. However, under disease conditions, expression levels of $\mathrm{S}_{1} \mathrm{P}_{4}$ in the brain are increased because infiltrated cells, particularly $\mathrm{T}$ cells, express $\mathrm{S}_{\mathrm{P}} \mathrm{P}_{4}[95,96]$. $\mathrm{S} 1 \mathrm{P}_{4}$ is also expressed on neutrophils known to play important roles in neuroinflammatory responses under disease conditions $[97,98] . \mathrm{S}_{4} \mathrm{P}_{4}$ can regulate the migration and infiltration of neutrophils and their inflammatory responses through 5-lipoxygenase activity [97]. In injured brains after an ischemic challenge, mRNA expression levels of $\mathrm{S1P}_{4}$ are increased and peaked at 4 days after tMCAO challenge [99]. Similarly, in injured spinal cords of EAE mice, mRNA expression levels of $\mathrm{S}_{4} \mathrm{P}_{4}$ are upregulated [100]. These independent in vivo studies indicate that $\mathrm{S}_{4} \mathrm{P}_{4}$ plays a critical role in the pathogenesis of stroke and MS. However, whether $\mathrm{S}_{4} \mathrm{P}_{4}$ can directly regulate the activation of microglia and their neuroinflammatory responses requires further investigation. 
${\mathrm{S} 1 \mathrm{P}_{5}}_{5}$ is moderately expressed on microglia [101]. Being a target of FTY720, $\mathrm{S}^{\mathrm{P}} \mathrm{P}_{5}$ must have certain roles in microglial biology, including microglial activation and proinflammatory responses. In fact, $\mathrm{S}_{1} \mathrm{P}_{5}$ is associated with microglial activation because an $\mathrm{S} \mathrm{P}_{5}$ agonist can significantly increase the number of Iba1-positive cells in organotypic cerebellar slice cultures [102]. Upon stimulation with Th1 cytokines, ozanimod can significantly reduce mRNA expression levels of proinflammatory cytokines including IL-6, RANTES, and TNF- $\alpha$ in striatal slice cultures from EAE mice as well as in Th1-stimulated BV2 microglial cells [64]. In addition, ozanimod can decrease the number of Iba1/IL-1 $\beta$-double immunopositive cells in corticostriatal slices from EAE mice [64], suggesting that it can inhibit inflammatory microglial activation. Considering that ozanimod can decrease mRNA expression levels of IL-1 $\beta$ and TNF- $\alpha$ while increasing FIZZ1 in Th1 cytokines-activated BV2 cells [64], ozanimod not only can inhibit M1 microglial phenotype but also can promote M2 microglial phenotype in EAE.

\section{S1P Receptors in Activation of Astrocytes and Their Neuroinflammatory Responses}

Receptor-mediated S1P signaling has been well characterized in astrogliosis (astrocyte activation) under different disease conditions. In the blood, platelets are considered the major source of S1P production [103,104]. In the CNS, astrocytes play such a role $[105,106]$. In fact, cerebellar astrocytes can release S1P $[105,106]$ to influence the proliferation of astrocytes by activating ERK1/2 signaling [106]. In spinal cord injuries, reactive astrocytes mainly found in injured areas can produce S1P, indicating that astrocytes are major sources of S1P in an injured spinal cord [107]. In addition to the role of cells producing S1P, astrocytes themselves can be activated by S1P. In addition, S1P can induce migration of astrocytes and promote the secretion of CXCL1, a chemokine, from reactive astrocytes [108], suggesting that $\mathrm{S} 1 \mathrm{P}$ can regulate the biology of astrocytes and their inflammatory responses. Therefore, S1P-influenced inflammatory astrogliosis can trigger the pathogenesis of diverse neuroinflammatory diseases. Indeed, it has been reported that S1P microinjection can result in a significant increase in astrogliosis in the corpus callosum of either normal or strokechallenged mice [27]. The observed astrogliosis has been thought to occur possibly via $\mathrm{S1P}_{1}$ activation because the administration of FTY720 with the highest binding affinity to S1P among S1P receptors $[109,110]$ can decrease the number of reactive astrocytes in the corpus callosum of normal or stroke-challenged mice [27]. FTY720 administration can also reduce mRNA expression levels of proinflammatory mediators (IL-6, IFN- $\gamma$, IL-1 $\beta$, TNF- $\alpha$, IL-12A, IL-23A, CXCL10, CCL2, CCL20, and NOS2) in astrocytes isolated from EAE mice [84]. Conversely, mRNA expression levels of anti-inflammatory mediators such as CXCL12 and IL-33 are upregulated after FTY720 administration [84]. In addition, microinjection of exogenous S1P into the striatum of a mouse brain can increase astrogliosis [111], suggesting that $\mathrm{S} 1 \mathrm{P}$ can induce neuroinflammation by promoting astrogliosis. Most S1P receptors $\left(\mathrm{S}_{1} \mathrm{P}_{1}, \mathrm{~S}_{1} \mathrm{P}_{2}, \mathrm{~S}_{1} \mathrm{P}_{3}\right.$, and $\left.\mathrm{S}_{1} \mathrm{P}_{5}\right)$ are expressed on astrocytes $[95,105,112]$. They can influence diverse biological events of astrocytes, such as proliferation, migration, communication between astrocytes and the blood-brain barrier gap junction, and production of growth factors [95]. Among S1P receptors expressed on astrocytes, $\mathrm{S1P}_{1}$ is the highest expressed receptor type, followed by $\mathrm{S}_{3} \mathrm{P}_{3}[112,113]$. Although the basal gene expression level of $\mathrm{S} \mathrm{P}_{5}$ is undetectable, its expression has been found to be increased in cultured astrocytes upon growth factor supplementation for 4-6 days [112,113]. Growth factor supplement (containing epidermal growth factor, basic fibroblast growth factor, insulin, biotin, human transferrin, and hydrocortisone) can dramatically increase mRNA expression levels of $\mathrm{S} \mathrm{P}_{5}$ in cultured astrocytes [113]. Among $\mathrm{S} 1 \mathrm{P}$ receptors, $\mathrm{S} \mathrm{P}_{1}$ and $\mathrm{S}_{1} \mathrm{P}_{3}$ can promote inflammatory activation of astrocytes, which has been well characterized in different disease conditions $[13,114,115]$.

The neuroinflammatory roles of $\mathrm{S}_{1} \mathrm{P}_{1}$ in astrocytes have been thoroughly studied in MS $[84,116]$. Protein expression levels of $\mathrm{S}_{1} \mathrm{P}_{1}$ and $\mathrm{S}_{1} \mathrm{P}_{3}$ are significantly increased in active MS lesions [117]. Upregulated $\mathrm{S}_{1} \mathrm{P}_{1}$ and $\mathrm{S}_{1} \mathrm{P}_{3}$ are mainly detected in reactive astrocytes [117], indicating that activation of these receptors on astrocytes may trigger 
inflammatory responses, thereby playing a role in the pathogenesis of MS. In human autopsy brain samples from MS patients, $\mathrm{S}_{1} \mathrm{P}_{1}$ has been found to be mainly upregulated in astrocytes and blood vessels, but not in myelin sheath or microglia/macrophages [118], suggesting that $\mathrm{S}_{1} \mathrm{P}_{1}$ on astrocytes is a critical pathogenic player in MS. In fact, neuroprotective effects of FTY720 in MS are mainly associated with modulation of astrocytic S1P activity $[43,82,119,120]$. In EAE, selective deletion of $\mathrm{S} \mathrm{P}_{1}$ from astrocytes, but not from neurons, can improve disease severity, demonstrating that astrocytic $\mathrm{S}_{1} \mathrm{P}_{1}$ is responsible for the pathogenesis of MS [43]. $\mathrm{S}_{1} \mathrm{P}_{1}$ deletion from astrocytes can also reduce protein expression levels of proinflammatory cytokines [43]. FTY720 can reduce migration and proliferation of S1P-stimulated cultured astrocytes mainly by downregulating $\mathrm{S}_{1} \mathrm{P}_{1}$ [121]. These effects of FTY720 can ameliorate spinal cord injury-induced functional deficits in rats [121]. In addition, FTY720 can influence astrocytes proliferation and reduce the secretion of inflammatory chemokines, astrogliosis, and neuroinflammation (reviewed well in [122]), all of which are associated with MS pathogenesis [123-125]. Furthermore, FTY720 treatment can decrease mRNA expression levels of proinflammatory mediators such as CCL2, NOS2, CSF2, IL-6, and TNF- $\alpha$, while increasing mRNA expression levels of antiinflammatory cytokines such as IL-10 in LPS-activated astrocytes culture [84], indicating its potent anti-inflammatory efficacy in activated astrocytes. In EAE mice, FTY720 can attenuate the upregulation of IL-1 receptor (IL-1R), $\mathrm{S}_{1} \mathrm{P}_{1}, \mathrm{~S}_{1} \mathrm{P}_{3}$, iNOS, and nitrotyrosine in astrocytes [126]. Neuroprotective effects of FTY720 in EAE are also mediated through the blockade of NO production and nuclear translocation of NF- $\mathrm{KB}$ in astrocytes [126]. These effects of FTY720 on inflammatory astrogliosis and MS pathogenesis might be due to its ability to suppress $\mathrm{S}_{1} \mathrm{P}_{1}$ activity [127]. Similarly, CYM-5442, a modulator of $\mathrm{S}_{1} \mathrm{P}_{1}$, can attenuate the severity of EAE and reduce amounts of proinflammatory mediators such as monocyte chemoattractant protein 1 (MCP-1), IL-17, IL-10, and IL-1 $\beta$ in blood plasma [82]. These effects of CYM-5442 are comparable to those of FTY720 [82]. S1P $\mathrm{P}_{1}$ is upregulated on neurons and astrocytes during EAE. Such upregulation is significantly attenuated by CYM-5442 treatment, indicating that downregulating $\mathrm{S}_{1} \mathrm{P}_{1}$ activity in astrocytes can reduce neuroinflammation and the severity of MS pathogenesis, at least in part [82]. Matrine, a natural alkaloid component extracted from Sophorae flavescens, can also attenuate astrogliosis in the brains of EAE mice [128]. This effect is mediated by lowering S1P amounts and suppressing SphK1/2 activity [128]. Matrine can also attenuate $\mathrm{S}_{1} \mathrm{P}_{1}$ upregulation in astrocytes in the brains of EAE mice [128], suggesting that the neuroprotective effects of Matrine in EAE mice are mediated through downregulation of $\mathrm{S}_{1} \mathrm{P}_{1}$ in astrocytes, which is reaffirmed in cultured astrocytes stimulated with IFN- $\gamma$ [128]. S1P $_{1}$ activation can also trigger ERK1/2 phosphorylation in mixed glial culture and astrocytes [129]. Since ERK1/2 signaling could contribute to MAPK-mediated inflammatory responses [130-132], S1P $\mathrm{P}_{1}$ activation can promote such inflammatory responses. All these findings clearly indicate that astrocytic $\mathrm{S}_{1} \mathrm{P}_{1}$ is the major $\mathrm{S} 1 \mathrm{P}$ receptor subtype responsible for neuroinflammation and disease pathogenesis of MS by modulating astrogliosis.

Roles of receptor-mediated S1P signaling, possibly through $\mathrm{S}_{1} \mathrm{P}_{1}$, in astrocytes have been indicated in other CNS diseases as well. Siponimod can block inflammatory activation of astrocytes as it can reduce nuclear translocation of NF- $\mathrm{KB}$ in IL-1 $\beta$ - or IL-17-stimulated astrocytes [133]. On the other hand, siponimod significantly increases expression levels of nuclear factor erythroid 2-related factor 2 (Nrf2), a potent antioxidant regulator [134]. These independent studies suggest its dual effects on astrocytes. Siponimod can also attenuate cell death of spinal neurons exposed to conditioned medium of S1P- or IL-1-treated astrocytes and induce $\mathrm{S}_{1} \mathrm{P}_{1}$ internalization [135]. Although whether siponimod can block ${\mathrm{S} 1 \mathrm{P}_{1}}_{1}$ recycling is not determined in that study [135], siponimod might reduce S1P-induced neurodegeneration via a functional antagonism of $\mathrm{S}_{1} \mathrm{P}_{1}$ in astrocytes. FTY720 can enhance the recovery after contusion-induced spinal cord injury in mice by attenuating the accumulation of reactive astrocytes in injured areas [136], which could be mediated by suppressing $\mathrm{S}_{1} \mathrm{P}_{1}$ activity because FTY720 has been proven to have a functional antagonistic effect on $\mathrm{S1P}_{1}$ [43-45]. Similarly, in APP/PS1 mice, FTY720 administration can attenuate astrocyte 
activation as evidenced by attenuated glial fibrillary acidic protein (GFAP) expression in the hippocampus and neocortex [73,74]. In addition, it can increase astrocytic phagocytosis of $A \beta$, suggesting that it not only attenuates neuroinflammatory activation of astrocytes but also contributes to the clearance of $A \beta$ plaque in AD pathogenesis [74]. FTY720 can also attenuate astrocyte activation in experimental models of PD [74,75]. It can decrease the number of GFAP-immunopositive cells in the substantia nigra and striatum at 21 days after exposing mice to 6-hydroxydopamine (6-OHDA) [75]. These studies indicate that FTY720 can exert its neuroprotective effects by attenuating astrocyte activation in different CNS pathogenesis. Such anti-neuroinflammatory activities of FTY720 in astrocytes might be mediated by downregulation of $\mathrm{S1P}_{1}$ activity as FTY720 has a functional antagonistic effect on $\mathrm{S}_{1} \mathrm{P}_{1}[43-45]$.

S1P can trigger the upregulation of mRNA and protein expression levels of COX-2 in astrocytes through the G 12 /13-Rho pathway [137]. This S1P-triggered COX-2 upregulation is mediated through $\mathrm{S}_{3} \mathrm{P}_{3}$ activation because such upregulation is attenuated upon $\mathrm{S} \mathrm{P}_{3}$ knockdown or its pharmacological inhibition [137]. Since COX-2 is considered a proinflammatory mediator in diverse disease conditions [138], suppressing $\mathrm{S}_{1} \mathrm{P}_{3}$ activity could lead to attenuation of $\mathrm{COX}$-2-mediated inflammatory responses. $\mathrm{S}_{1} \mathrm{P}_{3}$-mediated inflammatory responses in astrocytes have been reported by other independent studies as well. When murine or rat astrocytes are stimulated with TNF- $\alpha$ or LPS, mRNA expression levels of $\mathrm{S1P}_{3}$ are dramatically increased [139]. In addition, upon LPS stimulation, protein expression levels of $\mathrm{S1P}_{3}$ are increased in rat primary astrocytes [108]. Similarly, in cultured human astrocytes, mRNA expression levels of $\mathrm{S}_{1} \mathrm{P}_{3}$ are significantly increased upon TNF- $\alpha$ stimulation [117]. These independent studies indicate that astrocytic $\mathrm{S}_{3} \mathrm{P}_{3}$ can regulate inflammatory responses. Indeed, TNF- $\alpha$-stimulated astrocytes can secrete MCP-1, an inflammatory mediator [117] involved in the pathogenesis of diverse neuroinflammatory diseases [140]. Moreover, astrocytic $\mathrm{S}_{1} \mathrm{P}_{3}$ has been reported to participate in the pathogenesis of several neuroinflammatory diseases. In MS lesions, $\mathrm{S}^{\mathrm{P}_{3}}$ has been found to be dramatically upregulated in reactive astrocytes [108]. A recent study has revealed that $\mathrm{S} \mathrm{P}_{3}$ can regulate gene expression of inflammatory mediators in astrocytes through RhoA signaling pathways [137]. In a post-ischemic brain, pharmacological inhibition of $\mathrm{S}_{3} \mathrm{P}_{3}$ activity through administration of CAY10444 can attenuate astrogliosis, as evidenced by reduced GFAP immunoreactivity and astrocyte proliferation [94]. Particularly, at 3 days after the ischemic challenge, the number of reactive astrocytes is increased in injured brains, which is then reduced upon CAY10444 administration [94]. These results from a study using an in vivo cerebral ischemia model suggest that $\mathrm{S1P}_{3}$ can promote reactive astrogliosis in the post-ischemic brain. Similarly, in a mouse model of Sandhoff disease mainly characterized by reactive astrogliosis [141], genetic deletion of $\mathrm{S}_{1} \mathrm{P}_{3}$ can improve disease symptoms and attenuate astrogliosis [142]. In brain cancer, $\mathrm{S}_{1} \mathrm{P}_{3}$ is also upregulated in highly permeable metastases, mainly in astrocytes, where $\mathrm{S}_{1} \mathrm{P}_{3}$ influences the infiltration of peripheral immune cells and the production of inflammatory cytokines [143]. When astrocytic $\mathrm{S}_{3} \mathrm{P}_{3}$ activity is attenuated through its genetic knockdown, most inflammatory mediators (CCL2, CXCL1, CXCL10, intercellular adhesion molecule-1 (ICAM-1), IL-6, and IL-8) are downregulated at mRNA expression levels [143], reaffirming the neuroinflammatory roles of astrocytic $\mathrm{S}_{1} \mathrm{P}_{3}$. These studies clearly reflect the roles of $\mathrm{S}_{1} \mathrm{P}_{3}$ in reactive astrocytes and their neuroinflammatory responses during diverse pathological conditions. Mechanistically, neuroinflammatory roles of astrocytic $\mathrm{S} \mathrm{P}_{3}$ can be mediated through increased intracellular calcium signaling [91]. S1P-induced increase in intracellular calcium concentration is reduced upon pharmacological inhibition of $\mathrm{S} \mathrm{P}_{3}$ in rat primary cortical astrocytes, suggesting that $\mathrm{S} 1 \mathrm{P}$-influenced intracellular calcium stress is mediated by $\mathrm{S}_{1} \mathrm{P}_{3}$. As intracellular calcium overload is associated with diverse cellular responses, including neuroinflammation $[144,145]$, suppressing $\mathrm{S}_{1} \mathrm{P}_{3}$ activity can reduce astrocyte-dependent neuroinflammatory events. Indeed, S1P-stimulated CXCL1 chemokine production from cultured astrocytes is attenuated upon pharmacological inhibition of $\mathrm{S}_{1} \mathrm{P}_{3}$ [91], further supporting the neuroinflammatory roles of $\mathrm{S}_{1} \mathrm{P}_{3}$ in astrocytes. 
In a normal brain, $\mathrm{S} \mathrm{P}_{4}$ expression is negligible, whereas it is upregulated in an injured brain after an ischemic challenge [99]. However, how neuroglial $\mathrm{S}_{1} \mathrm{P}_{4}$ influences disease pathogenesis has not been reported yet. $\mathrm{S}^{\mathrm{P}_{5}}$ is also highly expressed on astrocytes and oligodendrocytes of active MS lesions as much as $\mathrm{S1P}_{1}$ [118], indicating that $\mathrm{S1P}_{5}$ might also modulate neuroinflammatory responses of astrocytes. A previous study has revealed that siponimod can inhibit NF- $\mathrm{KB}$ activation in IL-1 $\beta$-stimulated astrocytes [133], indicating possible roles of $\mathrm{S} \mathrm{P}_{5}$ in the activation of astrocytes and subsequent inflammatory responses. However, whether astrocytic $\mathrm{S}_{1} \mathrm{P}_{5}$ can influence neuroinflammatory events remains unclear. Instead, in oligodendrocytes, a main locus of $\mathrm{S}^{P_{5}}$ in the brain, $\mathrm{S} \mathrm{P}_{5}$ is known to have roles in regulating biological functions, including maturation, differentiation from neural stem cells to oligodendrocytes, and survival [146,147]. Further detailed studies about the roles of $\mathrm{S}_{1} \mathrm{P}_{4}$ and $\mathrm{S}_{1} \mathrm{P}_{5}$ in activation of astrocytes and their neuroinflammatory responses are needed.

Table 1 presents the biological roles of S1P receptors in the activation of neuroglia and their neuroinflammatory responses.

Although we discussed the role of receptor-mediated S1P signaling in the activation of microglia and/or astrocytes and their neuroinflammatory responses, there could be S1Pmediated glial crosstalk, resulting in neuroinflammatory responses. The proinflammatory mediators secreted by S1P-activated astrocytes or microglia might be able to further activate each other and prolong glial activation cascades. In fact, S1P signaling in both microglia and astrocytes has been reported to promote neuronal apoptosis [148], indicating a possible influence of S1P on neuron-glial crosstalk. However, whether S1P signaling is involved in the crosstalk between microglia and astrocytes remains unknown, which would be of interest for future studies.

Table 1. S1P receptors in activation of neuroglia and their neuroinflammatory responses. N/A: not available.

\begin{tabular}{|c|c|c|}
\hline Receptors & Microglia & Astrocytes \\
\hline $\mathrm{S}_{1} \mathrm{P}_{1}$ & 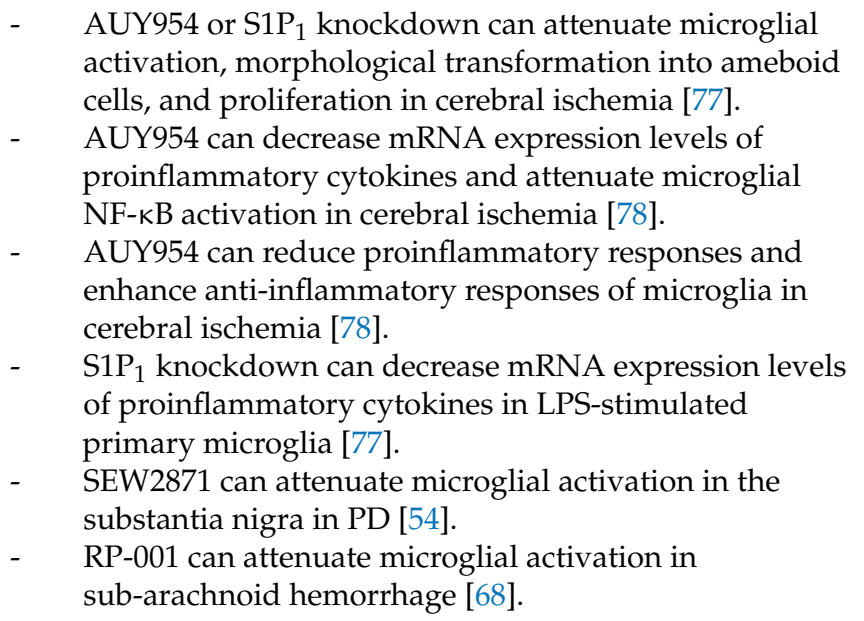 & 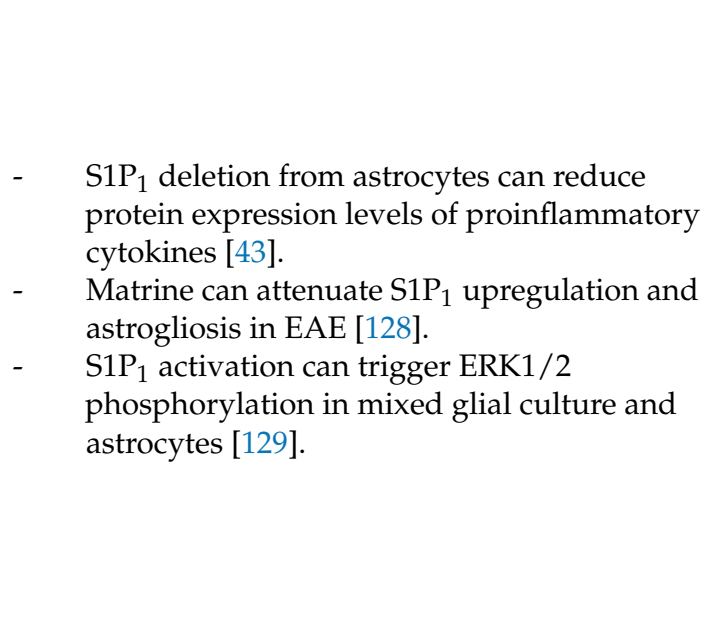 \\
\hline $\mathrm{S}_{1} \mathrm{P}_{2}$ & $\begin{array}{l}\text { - JTE013 can attenuate microglial activation, } \\
\text { morphological transformation into ameboid cells, and } \\
\text { proliferation in cerebral ischemia [87]. } \\
\text { JTE013 can attenuate proinflammatory responses of } \\
\text { microglia and their NF-kB activation in cerebral } \\
\text { ischemia [87]. } \\
\text { JTE013 or S1P knockdown can decrease mRNA } \\
\text { expression levels of proinflammatory cytokines in } \\
\text { LPS-stimulated BV2 microglia [87]. }\end{array}$ & $-\quad N / A$ \\
\hline
\end{tabular}


Table 1. Cont.

\begin{tabular}{|c|c|c|}
\hline Receptors & Microglia & Astrocytes \\
\hline $\mathrm{S}_{1} \mathrm{P}_{3}$ & $\begin{array}{l}\text { - CAY10444 can decrease microglial activation, } \\
\text { morphological transformation into ameboid cells, and } \\
\text { proliferation in cerebral ischemia [94]. } \\
\text { CAY10444 can attenuate proinflammatory responses of } \\
\text { microglia and their NF-kB activation in cerebral } \\
\text { ischemia [94]. } \\
\text { CAY10444 or } \mathrm{S}_{3} \mathrm{P}_{3} \text { knockdown can decrease mRNA } \\
\text { - } \\
\text { LPpression levels of proinflammatory cytokines in } \\
\text { LPS-stimulated primary microglia [94]. }\end{array}$ & 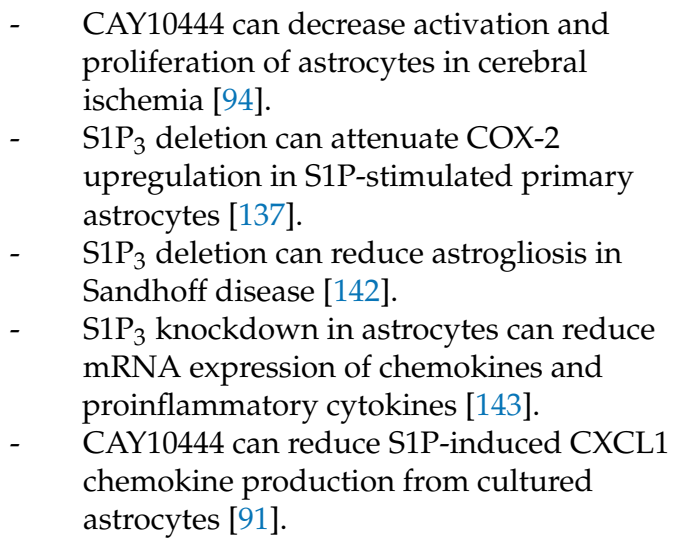 \\
\hline $\mathrm{S}_{1} \mathrm{P}_{4}$ & $-\quad N / A$ & $\mathrm{~N} / \mathrm{A}$ \\
\hline $\mathrm{S}_{1} \mathrm{P}_{5}$ & $\mathrm{~N} / \mathrm{A}$ & $-\quad N / A$ \\
\hline
\end{tabular}

\section{LPA Receptors in Activation of Microglia and Their Neuroinflammatory Responses}

LPA plays significant roles in microglial biology, such as motility, cytoskeletal architecture, membrane ruffling, glycolysis, brain-derived neurotrophic factor (BDNF) production, and ATP release $[149,150]$. Recent reports have suggested that LPA is one of the critical mediators of microglial activation $[28,151,152]$, further indicating that LPA and its receptormediated signaling might have critical roles in the pathogenies of diverse CNS disorders. LPA exposure can increase the metabolic activities of cultured microglia [29]. Especially, when microglia are exposed to LPA, their morphology is changed to a round shape with shorter and more thickened processes than resting microglia [149]. These morphological changes of microglia are characteristic features of activated ameboid microglia playing important roles in the pathogenesis of diverse CNS disorders [71,72]. In addition to functions demonstrated in vitro, LPA can trigger microglial activation in vivo. In neuropathic pain, intrathecal injection of LPA can induce microglial MAPK phosphorylation and upregulation of genes involved in microglial activation [29,149,153]. Minocycline, a specific inhibitor of microglial activation, can decrease LPA-induced mechanical allodynia and thermal hyperalgesia [154]. These effects of minocycline are also observed in sciatic inflammatory neuropathy [155]. These two independent studies clearly suggest that LPA-mediated neuropathic pain is caused by microglial activation, at least in part. In addition, intrathecal LPA injection not only can increase the number of activated microglia in the dorsal horn of the spinal cord but also can skew ramified microglia towards more toxic ameboid microglia [154]. Such microglial activation and morphological transformation by intrathecal LPA injection are associated with p38 MAPK phosphorylation [154]. In fact, it has been well demonstrated that LPA-mediated microglial activation can lead to the development of neuropathic pain at an early stage and that $\mathrm{LPA}_{1}$ plays a critical role in this process $[156,157]$

Among LPA receptors, $\mathrm{LPA}_{1}$ is expressed at the highest level in the brain and spinal cord $[28,158]$. While $\mathrm{LPA}_{1}$ is well expressed on primary microglia, it is undetectable in immortalized cell lines, for example, murine BV2 microglial cells [29,149,152,158,159]. It is clear that $\mathrm{LPA}_{1}$ is associated with the activation of microglia and their inflammatory responses in diverse neuroinflammatory diseases. In post-ischemic brains, $\mathrm{LPA}_{1}$ is associated with microglial activation, proliferation, and inflammatory responses [160-162]. Suppressing $\mathrm{LPA}_{1}$ activity with $\mathrm{LPA}_{1}$-specific shRNA lentivirus or AM152 (a specific antagonist for LPA also known as BMS-986020 [163-165]) can decrease the number of Iba1-positive microglia in the brains of mice challenged with tMCAO [160,162]. It can also reduce the soma sizes of microglia and attenuate microglial proliferation and morphological transformation from 
ramified microglia into ameboid cells in injured brains after tMCAO challenge [160,162]. These data indicate that $\mathrm{LPA}_{1}$ is associated with microglial activation in post-ischemic brains. Importantly, suppressing $\mathrm{LPA}_{1}$ activity can dramatically attenuate microglial NF- $\mathrm{kB}$ expression in post-ischemic brains and decrease mRNA expression levels of proinflammatory cytokines in mouse primary microglia exposed to LPS [162]. These findings clearly reflect that $\mathrm{LPA}_{1}$ can influence the inflammatory activation of microglia. A recent report has also demonstrated that $\mathrm{LPA}_{1}$ is upregulated in the brains of mice challenged with intracerebral hemorrhage (ICH) and that such upregulation is mainly observed in microglia [166]. Suppressing $\mathrm{LPA}_{1}$ activity with AM966 (another specific antagonist for $\mathrm{LPA}_{1}$ [167]) not only can reverse microglial activation but can also improve long-term neurobehavioral functions following ICH [166], indicating that microglial $\mathrm{LPA}_{1}$ is critically involved in the pathogenesis of ICH as in that of cerebral ischemia [160-162]. In addition, in a mouse model of spinal cord injury caused by an intraspinal injection of LPA, microglial activation and demyelination are significantly increased [28]. Either $\mathrm{LPA}_{1}$ knockout or pharmacological inhibition of $\mathrm{LPA}_{1}$ with AM095, an $\mathrm{LPA}_{1}$-selective antagonist [168], can attenuate LPAinduced demyelination in the spinal cord and promote cell survival when oligodendrocytes are exposed to microglial conditioned medium treated with LPA, indicating that $\mathrm{LPA}_{1}$ is a critical mediator of LPA-induced microglial activation [28]. Microglial activation is a hallmark pathogenic event in neuropathic pain, in which LPA/LPA 1 signaling is considered as a major factor in the pathogenesis of neuropathic pain $[156,169,170]$. $\mathrm{LPA}_{1}$ is also associated with microglial activation in an LPS-induced sepsis animal model [158]. In septic brains, $\mathrm{LPA}_{1}$ is associated with activation of microglia and their TNF- $\alpha$ production, which is recapitulated in LPS-stimulated rat primary microglia [158]. Suppressing $\mathrm{LPA}_{1}$ activity with $\mathrm{LPA}_{1}$-specific shRNA lentivirus can decrease the number of activated microglia and attenuate their proliferation in septic brains [158]. Similarly, in rat primary microglia, $\mathrm{LPA}_{1}$ knockdown with its specific siRNA can attenuate mRNA upregulation and protein release of TNF- $\alpha$ after LPS stimulation [158]. In SH-SY5Y cells co-cultured with BV2 microglia, saikosaponin-d, a natural triterpenoid saponin that acts as an inhibitor of $\mathrm{LPA}_{1}$ [171], can suppress neuronal $\mathrm{LPA}_{1}$ and MAP2 expression and reduce neuronal apoptosis as evidenced by increased protein expression levels of Bcl-2 with decreased Bax expression [171], revealing that microglial $\mathrm{LPA}_{1}$ is responsible for neuronal apoptosis. Saikosaponin-d not only can reduce microglial activation in the hippocampus of LPS-induced septic mouse, but also can attenuate proinflammatory cytokines production from LPS-stimulated primary microglia [172]. These aforementioned studies clearly suggest that $\mathrm{LPA}_{1}$ is a critical regulator of microglial activation, thus contributing to the pathogenesis of diverse CNS diseases.

$\mathrm{LPA}_{2}$ is expressed on microglia of the spinal cord, cultured primary microglia, BV2 murine microglia, and C13NJ microglia [149,152,173]. Microglial LPA 2 is responsible for oligodendrocyte cell death, possibly by enhancing the production of purines and subsequent activation of P2X7 signaling [173]. Conditioned medium obtained from LPA-stimulated microglia can decrease the number of myelin basic protein (MBP)-positive cells and induce cell death of oligodendrocytes, suggesting that microglial $\mathrm{LPA}_{2}$ is responsible for this death of oligodendrocytes [173]. In fact, such regulatory roles of $\mathrm{LPA}_{2}$ are linked to the pathogenesis of spinal cord injury [173].

$\mathrm{LPA}_{3}$ is abundantly expressed on microglia [29]. Its expression is further increased in activated microglia [101]. Interestingly, microglial $\mathrm{LPA}_{3}$ is associated with LPA production $[154,156]$. The $\mathrm{LPA} / \mathrm{LPA}_{3}$ signaling axis can influence the pathogenesis of neuropathic pain $[154,156]$. In addition, $\mathrm{LPA}_{3}$ can trigger the production of IL- $1 \beta$ from microglia, resulting in inflammatory cascades $[154,170]$. LPA 3 is also associated with increased ERK1/2 phosphorylation in LPA-stimulated microglia [149]. Considering that ERK1/2 activation can trigger the production of inflammatory mediators [130-132], LPA $_{3}$-regulated ERK1/2 activation might be an underlying event that promotes neuroinflammatory responses in microglia. In addition, LPA-induced membrane ruffling of activated microglia can be mediated through $\mathrm{LPA}_{3}$ [150] because it is attenuated by DGPP [150], a potent $\mathrm{LPA}_{3}$ antagonist [174]. Such findings [150] suggest that $\mathrm{LPA}_{3}$ is a critical modulator of microglial activation, indirectly supporting the previously reported roles of $\mathrm{LPA}_{3}$ in microglial neuroinflammatory responses $[154,170]$. In 
addition, Ki16425, a dual inhibitor of $\mathrm{LPA}_{1}$ and $\mathrm{LPA}_{3}$ [175], can attenuate LPA-induced ROS production in EOC mouse microglial cells, indicating that $\mathrm{LPA}_{3}$ can influence microglial oxidative stress [176]. Collectively, these studies indicate that $\mathrm{LPA}_{3}$ is associated with inflammatory microglial activation and oxidative stress under pathological conditions.

$\mathrm{LPA}_{4}$ is moderately expressed in a normal mouse brain, primary microglia, and BV2 microglia [158], suggesting its certain role in microglial biology. However, its role in microglial biology and related disease pathogenies has not been reported yet.

$\mathrm{LPA}_{5}$ is well expressed on microglia [177]. The association of LPA 5 with microglial activation has been validated in both in vitro microglial culture and in vivo animal models. In LPA-stimulated primary microglia or BV2 microglial cell line, TCLPA5, a selective antagonist for $\mathrm{LPA}_{5}$ [178], can attenuate the upregulation of M1-related markers (such as iNOS, COX-2, CD40, and CD86) and proinflammatory cytokines (such as IL-1 $\beta$ and IL-6) [152]. In BV2 microglial cells, $\mathrm{LPA}_{5}$ knockdown with its specific siRNA can attenuate the production of proinflammatory cytokines (TNF- $\alpha$, IL-1 $\beta$, and IL-6) [179]. In addition, other LPA antagonists, such as AS2717638 and compound 3, can attenuate LPA-induced production of proinflammatory cytokines (TNF- $\alpha$, IL-1 $\beta$, and IL-6) and chemokines (CXCL10, CXCL2, and CCL5), all of which are markers of M1 microglia [180], indicating that the LPA/LPA signaling axis is important for the proinflammatory M1 activation of microglia. The LPA/LPA signaling axis is also associated with the activation of microglial MAPK signaling pathways, which subsequently promotes the activation of NF- $\mathrm{KB}$ and STAT $1 / 3$ signaling pathways in LPA-stimulated microglial cultures [181]. Importantly, LPA 5 activation can increase the sizes of microglia and promote morphological transformation into ameboid-shaped microglia [181], further suggesting that $\mathrm{LPA}_{5}$ can promote inflammatory microglial activation in cultured microglia. This notion is also supported by studies employing an in vivo stroke model. In fact, $\mathrm{LPA}_{5}$ has been demonstrated to be a novel pathogenic factor for both acute and chronic ischemic injuries in mice subjected to $\mathrm{MCAO}$ challenge because TCLPA5 not only can attenuate acute brain damage but also exert long-term neuroprotection in these mice $[179,182]$. Such a pathogenic role of $\mathrm{LPA}_{5}$ is closely associated with microglial activation in injured brains [179]. LPA 5 can influence microglial activation and proliferation in post-ischemic brains [179]. The pharmacological inhibition of LPA 5 with TCLPA5 can decrease the number of activated microglia in peri-ischemic and ischemic core regions and attenuate microglial proliferation in the penumbra region after tMCAO challenge [179]. TCLPA5 administration can also attenuate the morphological transformation of activated microglia from ramified into ameboid shape in post-ischemic brains [179]. In addition, it can attenuate the upregulation of M1-relevant proinflammatory markers (TNF- $\alpha$, IL-1 $\beta$, and IL-6) and microglial NF- $\mathrm{KB}$ activation in injured brains after $\mathrm{tMCAO}$ challenge [179]. The latter indicates that the observed $\mathrm{LPA}_{5}$-driven upregulation of M1-like proinflammatory cytokines may occur in microglia. This notion has been reaffirmed in cultured microglia in vitro $[179,180]$. Interestingly, $\mathrm{LPA}_{5}$ is upregulated in post-ischemic brains. Such upregulation is observed mostly in Iba1-positive cells (activated microglia) [179], indicating that $\mathrm{LPA}_{5}$ is the critical regulator of microglial activation in post-ischemic brains.

$\mathrm{LPA}_{6}$ is also highly expressed on mouse primary microglia and BV2 murine microglia [158]. However, its role in neuroinflammatory disease conditions remains unclear.

\section{LPA Receptors in Activation of Astrocytes and Their Neuroinflammatory Responses}

Receptor-mediated LPA signaling can also influence the activation of astrocytes in different CNS disease conditions. Autotaxin, a key enzyme of LPA synthesis [183], can promote adhesion of astrocytes and glioma invasion during glioblastoma multiforme pathogenesis [184], indicating that LPA can regulate astrocyte biology. LPA can induce the formation of stress fibers and focal adhesions [185] and increase intracellular calcium concentration in astrocytes, [186], all of which can stimulate astrocytic proliferation and migration [187-190] that are featured biological events of reactive astrocytes [190-192].

In a normal brain, $\mathrm{LPA}_{1}$ is highly expressed on astrocytes [113,166,193,194], indicating that $\mathrm{LPA}_{1}$ can influence astrocyte activation. A few recent studies have demonstrated such 
a role. In cultured astrocytes that express $\mathrm{LPA}_{1}$ abundantly, LPA can induce cell proliferation via $\mathrm{LPA}_{1}$ [195]. LPA can also promote the migration of LPS- or IL-1 $\beta$-stimulated rat primary astrocytes mediated through $\mathrm{LPA}_{1}$ [196]. In C6 glioma cells, an immortalized astrocyte cell line, inhibition of $\mathrm{LPA}_{1}$ activity by Ki16425 (an LPA $1 / 3$ antagonist) or AM966 (an $\mathrm{LPA}_{1}$ antagonist) can attenuate LPA-triggered ERK1/2 activation, which is reaffirmed by $\mathrm{LPA}_{1}$ knockdown with its specific siRNA [197]. Inactivation of ERK1/2 by suppressing $\mathrm{LPA}_{1}$ activity could lead to attenuated proinflammatory responses in diverse CNS diseases such as cerebral ischemia [161,162]. In fact, inhibiting LPA signaling through its specific antagonist, AM095, can attenuate the activation and proliferation of astrocytes in post-ischemic brains, which might ultimately contribute to neuroprotection [162]. Besides cerebral ischemia, $\mathrm{LPA}_{1}$ may have certain roles in the activation of astrocytes and their neuroinflammatory responses in other disease types. As discussed earlier, either AM966 administration or genetic deletion of $\mathrm{LPA}_{1}$ can attenuate brain damages and neuroinflammatory responses in ICH-challenged mice [166]. In the injured brains of these mice, $\mathrm{LPA}_{1}$ is upregulated on reactive astrocytes, activated microglia, and neurons [166]. However, whether $\mathrm{LPA}_{1}$ could regulate astrocyte activation and whether the observed neuroinflammation is dependent on any of those cell types in ICH-challenged mice remains unknown. In a neuropathic pain model by a partial sciatic nerve ligation, $\mathrm{LPA}_{1}$ has been indicated as a possible mediator for the activation of astrocytes and their production of chemokine (CXCL1) in injured spinal dorsal horns, leading to the aggravation of pathogenesis because $\mathrm{LPA}_{1 / 3}$ antagonist (Ki16425) can attenuate CXCL1 upregulation in activated astrocytes [198]. Although $\mathrm{LPA}_{1}$ can influence a variety of functions of astrocytes [195,196], many of its roles in astrocyte-dependent neuroinflammation remain unclear.

$\mathrm{LPA}_{2}$ is also highly expressed on astrocytes [193], indicating that $\mathrm{LPA}_{2}$ might also play a critical role in neuroinflammatory responses. Similarly, other LPA receptors, including $\mathrm{LPA}_{3}, \mathrm{LPA}_{4}$, and $\mathrm{LPA}_{6}$, are also expressed on astrocytes [195,199], suggesting that these receptors might have certain roles in the neuroinflammatory responses of astrocytes. However, the roles of these LPA receptor subtypes in astrocyte activation and their neuroinflammatory responses have not been reported yet.

Table 2 presents the biological roles of LPA receptors in the activation of neuroglia and their neuroinflammatory responses.

Table 2. LPA receptors in neuroglial activation and their neuroinflammatory responses. N/A: not available.

\begin{tabular}{|c|c|c|}
\hline Receptors & Microglia & Astrocytes \\
\hline $\mathrm{LPA}_{1}$ & 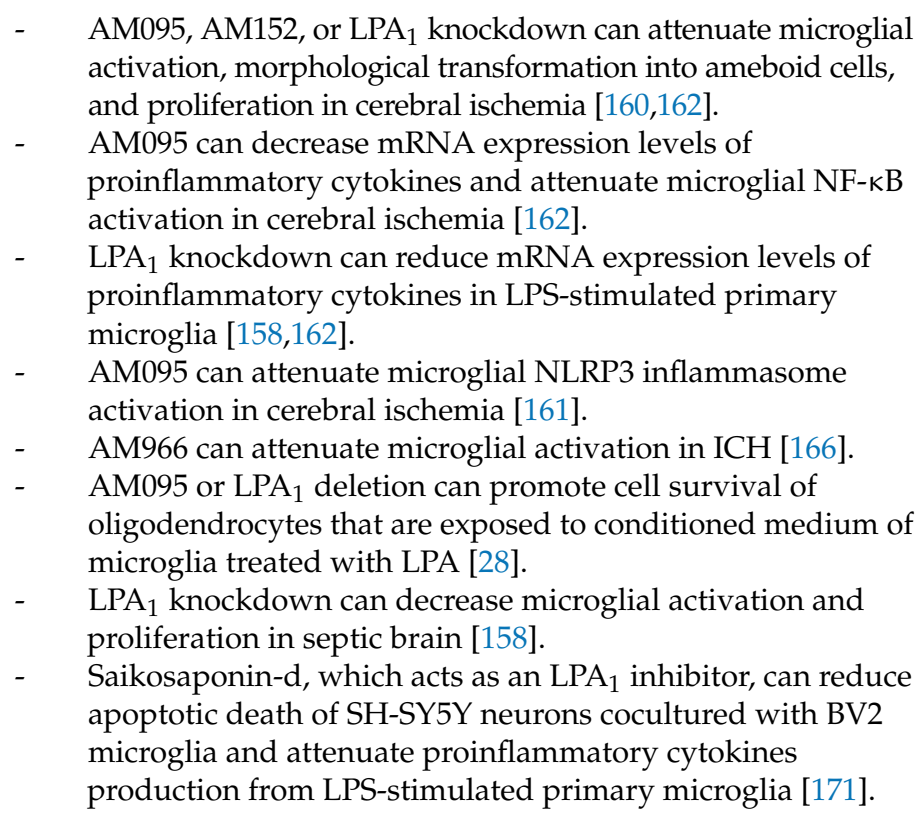 & 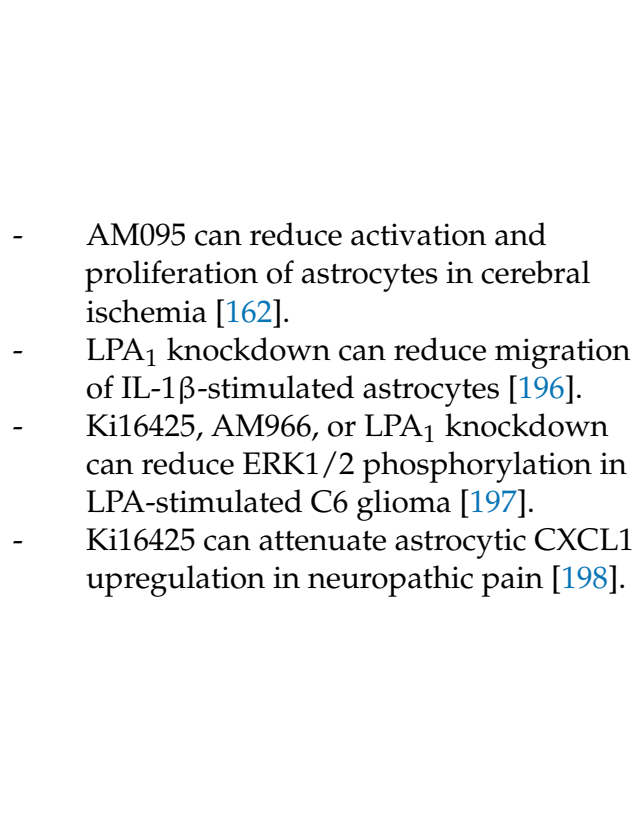 \\
\hline
\end{tabular}


Table 2. Cont

\begin{tabular}{|c|c|c|}
\hline Receptors & Microglia & Astrocytes \\
\hline $\mathrm{LPA}_{2}$ & $\begin{array}{l}\text { - } \mathrm{LPA}_{2} \text { deletion in microglia can promote cell survival of } \\
\text { oligodendrocytes that are exposed to conditioned medium of } \\
\text { microglia treated with LPA [173]. }\end{array}$ & $-\quad N / A$ \\
\hline $\mathrm{LPA}_{3}$ & $\begin{array}{l}\text { - } \quad \text { DGPP can attenuate LPA-induced membrane ruffling of } \\
\text { activated microglia [150]. } \\
\text { Ki16425 can attenuate ERK1/2 phosphorylation in } \\
\text { LPA-stimulated microglia [149]. } \\
\text { - } \quad \text { Ki16425 can attenuate ROS production from LPA-stimulated } \\
\text { EOC mouse microglial cells [176]. }\end{array}$ & $\begin{array}{l}\text { - } \quad \text { Ki16425 can attenuate astrocytic CXCL1 } \\
\text { upregulation in neuropathic pain [198]. }\end{array}$ \\
\hline $\mathrm{LPA}_{4}$ & $-\quad N / A$ & $-\quad \mathrm{N} / \mathrm{A}$ \\
\hline $\mathrm{LPA}_{5}$ & 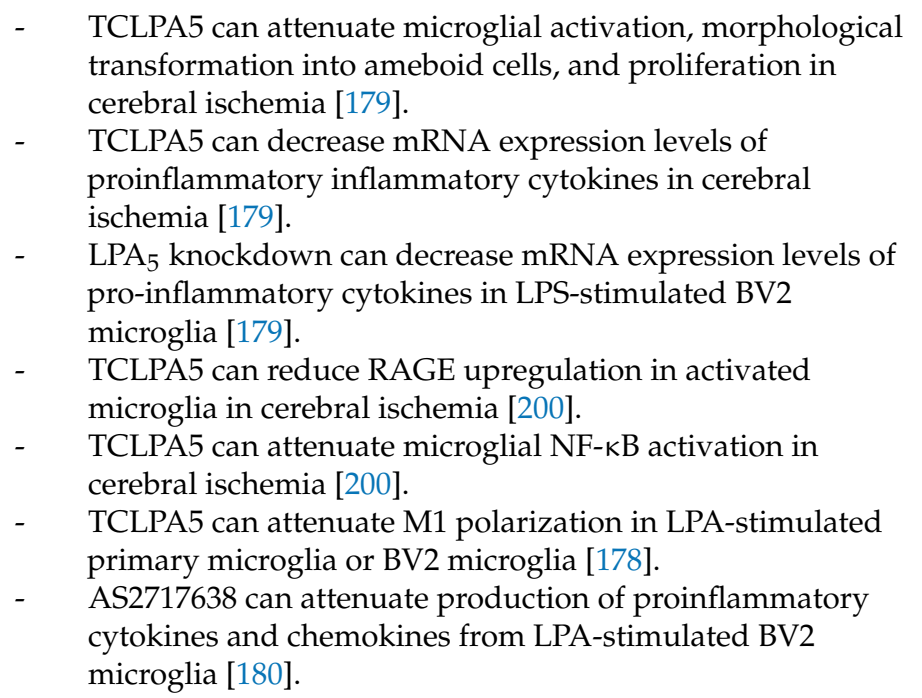 & $-\quad N / A$ \\
\hline $\mathrm{LPA}_{6}$ & $\mathrm{~N} / \mathrm{A}$ & $\mathrm{N} / \mathrm{A}$ \\
\hline
\end{tabular}

\section{Conclusions}

Most LPA and S1P receptors can modulate neuroinflammatory responses by influencing the activation of microglia and astrocytes. S1P and LPA receptors are expressed on both cell types, and most of these expressed receptors are upregulated during CNS pathogenesis. Tables 1 and 2 present the biological roles of S1P and LPA receptors in glial activation and their neuroinflammatory responses. Figure 1 schematically illustrates the neuroinflammatory responses of $\mathrm{S} 1 \mathrm{P}$ and LPA receptors. $\mathrm{Up}$ to date, it has been reported that $\mathrm{S}_{1} \mathrm{P}_{1}, \mathrm{~S}_{1} \mathrm{P}_{2}$, $\mathrm{S}_{1} \mathrm{P}_{3}, \mathrm{~S}_{1} \mathrm{P}_{5}, \mathrm{LPA}_{1}$, and $\mathrm{LPA}_{5}$ can promote the activation of microglia and/or astrocytes and their neuroinflammatory responses. However, the roles of other receptors such as $\mathrm{S}_{1} \mathrm{P}_{4}, \mathrm{LPA}_{2}, \mathrm{LPA}_{4}$, and $\mathrm{LPA}_{6}$ remain unclear, possibly due to the lack of pharmacological modulators for these receptor subtypes. Therefore, future studies should focus on the development of receptor-specific modulators and the use of genetic tools for verifying the roles of specific receptor subtypes in the activation of microglia and/or astrocytes. Since the roles of LPA and S1P receptors in glial activation have been mainly studied in cerebral ischemia and MS, future studies should also focus on whether these receptors can influence the activation of microglia and/or astrocytes in other CNS diseases such as PD, AD, and Huntington's disease. Moreover, developing new modulators of S1P and LPA receptor subtypes could be an appealing therapeutic option to manage CNS diseases featured by the activation of microglia and astrocytes and their inflammatory responses. 


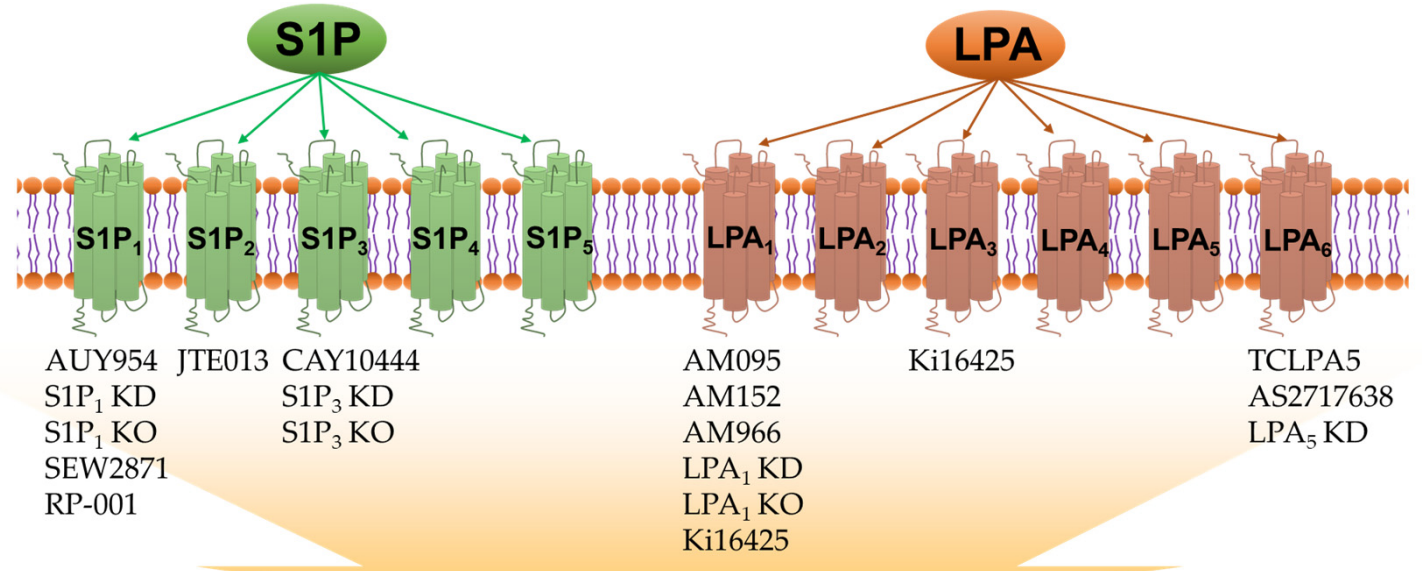

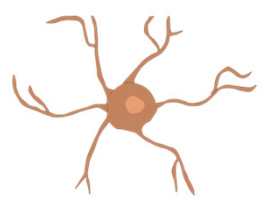

Resting microglia

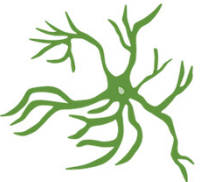

Resting astrocyte

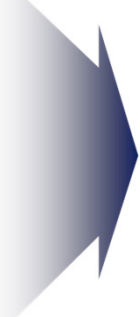

Activated astrocyte

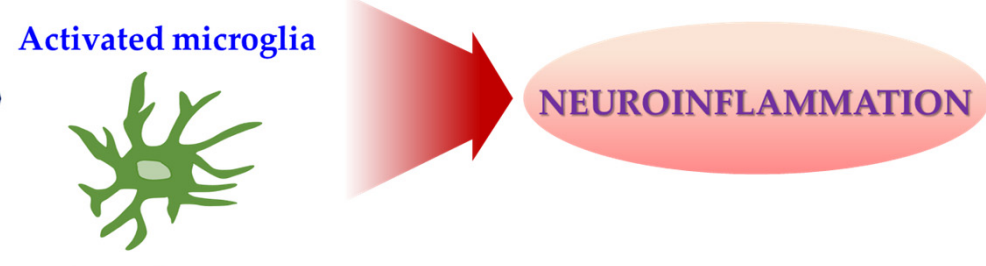

Figure 1. Either pharmacological or genetic approaches have been employed to identify roles of S1P and LPA receptors in glial activation under neuroinflammatory conditions. Receptor-mediated S1P and LPA signaling can promote the activation of microglia and astrocytes in various CNS pathologies. Activated microglia or activated astrocytes can secrete diverse proinflammatory mediators, including cytokines and chemokines, all of which can trigger neuroinflammatory events and contribute to CNS pathogenesis. Pharmacological or genetic tools listed below each receptor subtype can suppress the activity of the respective receptor. They have been reported to attenuate neuroinflammatory responses of activated microglia or activated astrocytes. $\mathrm{Up}$ to date, $\mathrm{S}_{1} \mathrm{P}_{1}, \mathrm{~S}_{1} \mathrm{P}_{2}, \mathrm{~S}_{1} \mathrm{P}_{3}, \mathrm{~S}_{1} \mathrm{P}_{5}, \mathrm{LPA}_{1}$, and $\mathrm{LPA}_{5}$ have been identified as the receptors involved in such events. See text for details and references. KD: knockdown; KO: knockout.

Author Contributions: Writing—original draft preparation, B.P.G. and J.-W.C.; writing-review and editing, B.P.G. and J.-W.C.; visualization, B.P.G. and J.-W.C.; supervision, J.-W.C.; funding acquisition, J.-W.C. All authors have read and agreed to the published version of the manuscript.

Funding: This research was supported by grants (NRF-2021R1A2C1005520 and NRF-2020R1A6A1A0 3043708 to J.-W.C.) of the National Research Foundation (NRF) of Korea.

Conflicts of Interest: The authors declare no conflict of interest.

\section{References}

1. Jakel, S.; Dimou, L. Glial Cells and Their Function in the Adult Brain: A Journey through the History of Their Ablation. Front. Cell. Neurosci. 2017, 11, 24. [CrossRef]

2. Fields, R.D.; Stevens-Graham, B. New insights into neuron-glia communication. Science 2002, 298, 556-562. [CrossRef]

3. Meyer, K.; Kaspar, B.K. Glia-neuron interactions in neurological diseases: Testing non-cell autonomy in a dish. Brain Res. 2017, 1656, 27-39. [CrossRef] [PubMed]

4. Tognatta, R.; Miller, R.H. Contribution of the oligodendrocyte lineage to CNS repair and neurodegenerative pathologies. Neuropharmacology 2016, 110, 539-547. [CrossRef] [PubMed]

5. Kabba, J.A.; Xu, Y.; Christian, H.; Ruan, W.; Chenai, K.; Xiang, Y.; Zhang, L.; Saavedra, J.M.; Pang, T. Microglia: Housekeeper of the Central Nervous System. Cell. Mol. Neurobiol. 2018, 38, 53-71. [CrossRef]

6. Gopinath, A.; Collins, A.; Khoshbouei, H.; Streit, W.J. Microglia and Other Myeloid Cells in Central Nervous System Health and Disease. J. Pharmacol. Exp. Ther. 2020, 375, 154-160. [CrossRef] 
7. Nedergaard, M.; Ransom, B.; Goldman, S.A. New roles for astrocytes: Redefining the functional architecture of the brain. Trends Neurosci. 2003, 26, 523-530. [CrossRef] [PubMed]

8. Colonna, M.; Butovsky, O. Microglia Function in the Central Nervous System During Health and Neurodegeneration. Annu. Rev. Immunol. 2017, 35, 441-468. [CrossRef]

9. Liddelow, S.; Barres, B. SnapShot: Astrocytes in Health and Disease. Cell 2015, 162, 1170. [CrossRef] [PubMed]

10. Griffiths, M.R.; Gasque, P.; Neal, J.W. The regulation of the CNS innate immune response is vital for the restoration of tissue homeostasis (repair) after acute brain injury: A brief review. Int. J. Inflam. 2010, 2010, 151097. [CrossRef]

11. Saxena, S.; Kruys, V.; Vamecq, J.; Maze, M. The Role of Microglia in Perioperative Neuroinflammation and Neurocognitive Disorders. Front. Aging Neurosci. 2021, 13, 671499. [CrossRef]

12. Anderson, M.A.; Burda, J.E.; Ren, Y.; Ao, Y.; O’Shea, T.M.; Kawaguchi, R.; Coppola, G.; Khakh, B.S.; Deming, T.J.; Sofroniew, M.V. Astrocyte scar formation aids central nervous system axon regeneration. Nature 2016, 532, 195-200. [CrossRef]

13. Kwon, H.S.; Koh, S.H. Neuroinflammation in neurodegenerative disorders: The roles of microglia and astrocytes. Transl. Neurodegener. 2020, 9, 42. [CrossRef] [PubMed]

14. Chun, J.; Rosen, H. Lysophospholipid receptors as potential drug targets in tissue transplantation and autoimmune diseases. Curr. Pharm. Des. 2006, 12, 161-171. [CrossRef]

15. Rosen, H.; Goetzl, E.J. Sphingosine 1-phosphate and its receptors: An autocrine and paracrine network. Nat. Rev. Immunol. 2005, 5, 560-570. [CrossRef]

16. Ross, B.M.; Kish, S.J. Characterization of lysophospholipid metabolizing enzymes in human brain. J. Neurochem. 1994, 63, 1839-1848. [CrossRef]

17. Choi, J.W.; Chun, J. Lysophospholipids and their receptors in the central nervous system. Biochim. Biophys. Acta 2013, 1831, 20-32. [CrossRef]

18. Choi, J.W.; Herr, D.R.; Noguchi, K.; Yung, Y.C.; Lee, C.W.; Mutoh, T.; Lin, M.E.; Teo, S.T.; Park, K.E.; Mosley, A.N.; et al. LPA receptors: Subtypes and biological actions. Annu. Rev. Pharmacol. Toxicol. 2010, 50, 157-186. [CrossRef] [PubMed]

19. Rao, P.V. Bioactive lysophospholipids: Role in regulation of aqueous humor outflow and intraocular pressure in the context of pathobiology and therapy of glaucoma. J. Ocul. Pharmacol. Ther. 2014, 30, 181-190. [CrossRef] [PubMed]

20. Rivera, R.; Chun, J. Biological effects of lysophospholipids. Rev. Physiol. Biochem. Pharmacol. 2008, 160, 25-46. [CrossRef]

21. Shao, Y.; Nanayakkara, G.; Cheng, J.; Cueto, R.; Yang, W.Y.; Park, J.Y.; Wang, H.; Yang, X. Lysophospholipids and Their Receptors Serve as Conditional DAMPs and DAMP Receptors in Tissue Oxidative and Inflammatory Injury. Antioxid. Redox. Signal. 2018, 28, 973-986. [CrossRef]

22. Binder, B.Y.; Williams, P.A.; Silva, E.A.; Leach, J.K. Lysophosphatidic Acid and Sphingosine-1-Phosphate: A Concise Review of Biological Function and Applications for Tissue Engineering. Tissue Eng. Part B Rev. 2015, 21, 531-542. [CrossRef]

23. Tan, S.T.; Ramesh, T.; Toh, X.R.; Nguyen, L.N. Emerging roles of lysophospholipids in health and disease. Prog. Lipid. Res. 2020, 80, 101068. [CrossRef]

24. Hao, Y.; Guo, M.; Feng, Y.; Dong, Q.; Cui, M. Lysophospholipids and Their G-Coupled Protein Signaling in Alzheimer's Disease: From Physiological Performance to Pathological Impairment. Front. Mol. Neurosci. 2020, 13, 58. [CrossRef]

25. Crack, P.J.; Zhang, M.; Morganti-Kossmann, M.C.; Morris, A.J.; Wojciak, J.M.; Fleming, J.K.; Karve, I.; Wright, D.; Sashindranath, M.; Goldshmit, Y.; et al. Anti-lysophosphatidic acid antibodies improve traumatic brain injury outcomes. J. Neuroinflamm. 2014, 11, 37. [CrossRef]

26. Goldshmit, Y.; Matteo, R.; Sztal, T.; Ellett, F.; Frisca, F.; Moreno, K.; Crombie, D.; Lieschke, G.J.; Currie, P.D.; Sabbadini, R.A.; et al. Blockage of lysophosphatidic acid signaling improves spinal cord injury outcomes. Am. J. Pathol. 2012, 181, 978-992. [CrossRef] [PubMed]

27. Moon, E.; Han, J.E.; Jeon, S.; Ryu, J.H.; Choi, J.W.; Chun, J. Exogenous S1P Exposure Potentiates Ischemic Stroke Damage That Is Reduced Possibly by Inhibiting S1P Receptor Signaling. Mediat. Inflamm. 2015, 2015, 492659. [CrossRef] [PubMed]

28. Santos-Nogueira, E.; Lopez-Serrano, C.; Hernandez, J.; Lago, N.; Astudillo, A.M.; Balsinde, J.; Estivill-Torrus, G.; de Fonseca, F.R.; Chun, J.; Lopez-Vales, R. Activation of Lysophosphatidic Acid Receptor Type 1 Contributes to Pathophysiology of Spinal Cord Injury. J. Neurosci. 2015, 35, 10224-10235. [CrossRef]

29. Moller, T.; Contos, J.J.; Musante, D.B.; Chun, J.; Ransom, B.R. Expression and function of lysophosphatidic acid receptors in cultured rodent microglial cells. J. Biol. Chem. 2001, 276, 25946-25952. [CrossRef] [PubMed]

30. Suckau, O.; Gross, I.; Schrotter, S.; Yang, F.; Luo, J.; Wree, A.; Chun, J.; Baska, D.; Baumgart, J.; Kano, K.; et al. LPA1, LPA2, LPA4, and LPA6 receptor expression during mouse brain development. Dev. Dyn. 2019, 248, 375-395. [CrossRef]

31. Kajitani, N.; Okada-Tsuchioka, M.; Kano, K.; Omori, W.; Boku, S.; Aoki, J.; Takebayashi, M. Differential anatomical and cellular expression of lysophosphatidic acid receptor 1 in adult mouse brain. Biochem. Biophys. Res. Commun. 2020, 531, 89-95. [CrossRef]

32. Healy, L.M.; Antel, J.P. Sphingosine-1-Phosphate Receptors in the Central Nervous and Immune Systems. Curr. Drug Targets 2016, 17, 1841-1850. [CrossRef]

33. Gaire, B.P.; Choi, J.W. Sphingosine 1-Phosphate Receptors in Cerebral Ischemia. Neuromolecular Med. 2021, 23, 211-223. [CrossRef] [PubMed]

34. Karunakaran, I.; Alam, S.; Jayagopi, S.; Frohberger, S.J.; Hansen, J.N.; Kuehlwein, J.; Holbling, B.V.; Schumak, B.; Hubner, M.P.; Graler, M.H.; et al. Neural sphingosine 1-phosphate accumulation activates microglia and links impaired autophagy and inflammation. Glia 2019, 67, 1859-1872. [CrossRef] [PubMed] 
35. Zahiri, D.; Burow, P.; Grossmann, C.; Muller, C.E.; Klapperstuck, M.; Markwardt, F. Sphingosine-1-phosphate induces migration of microglial cells via activation of volume-sensitive anion channels, ATP secretion and activation of purinergic receptors. Biochim. Biophys. Acta Mol. Cell. Res. 2021, 1868, 118915. [CrossRef] [PubMed]

36. Juntunen, M.; Hagman, S.; Moisan, A.; Narkilahti, S.; Miettinen, S. In Vitro Oxygen-Glucose Deprivation-Induced Stroke Models with Human Neuroblastoma Cell- and Induced Pluripotent Stem Cell-Derived Neurons. Stem. Cells Int. 2020, $2020,8841026$. [CrossRef]

37. Ryou, M.G.; Mallet, R.T. An In Vitro Oxygen-Glucose Deprivation Model for Studying Ischemia-Reperfusion Injury of Neuronal Cells. Methods Mol. Biol. 2018, 1717, 229-235. [CrossRef] [PubMed]

38. Lv, M.; Zhang, D.; Dai, D.; Zhang, W.; Zhang, L. Sphingosine kinase 1/sphingosine-1-phosphate regulates the expression of interleukin-17A in activated microglia in cerebral ischemia/reperfusion. Inflamm. Res. 2016, 65, 551-562. [CrossRef] [PubMed]

39. Blondeau, N.; Lai, Y.; Tyndall, S.; Popolo, M.; Topalkara, K.; Pru, J.K.; Zhang, L.; Kim, H.; Liao, J.K.; Ding, K.; et al. Distribution of sphingosine kinase activity and mRNA in rodent brain. J. Neurochem. 2007, 103, 509-517. [CrossRef]

40. Nayak, D.; Huo, Y.; Kwang, W.X.; Pushparaj, P.N.; Kumar, S.D.; Ling, E.A.; Dheen, S.T. Sphingosine kinase 1 regulates the expression of proinflammatory cytokines and nitric oxide in activated microglia. Neuroscience 2010, 166, 132-144. [CrossRef] [PubMed]

41. Brinkmann, V.; Davis, M.D.; Heise, C.E.; Albert, R.; Cottens, S.; Hof, R.; Bruns, C.; Prieschl, E.; Baumruker, T.; Hiestand, P.; et al. The immune modulator FTY720 targets sphingosine 1-phosphate receptors. J. Biol. Chem. 2002, 277, 21453-21457. [CrossRef]

42. Pitman, M.R.; Woodcock, J.M.; Lopez, A.F.; Pitson, S.M. Molecular targets of FTY720 (fingolimod). Curr. Mol. Med. 2012, 12, 1207-1219. [CrossRef]

43. Choi, J.W.; Gardell, S.E.; Herr, D.R.; Rivera, R.; Lee, C.W.; Noguchi, K.; Teo, S.T.; Yung, Y.C.; Lu, M.; Kennedy, G.; et al. FTY720 (fingolimod) efficacy in an animal model of multiple sclerosis requires astrocyte sphingosine 1-phosphate receptor 1 (S1P1) modulation. Proc. Natl. Acad. Sci. USA 2011, 108, 751-756. [CrossRef] [PubMed]

44. Graler, M.H.; Goetzl, E.J. The immunosuppressant FTY720 down-regulates sphingosine 1-phosphate G-protein-coupled receptors. FASEB J. 2004, 18, 551-553. [CrossRef]

45. Oo, M.L.; Thangada, S.; Wu, M.T.; Liu, C.H.; Macdonald, T.L.; Lynch, K.R.; Lin, C.Y.; Hla, T. Immunosuppressive and antiangiogenic sphingosine 1-phosphate receptor-1 agonists induce ubiquitinylation and proteasomal degradation of the receptor. J. Biol. Chem. 2007, 282, 9082-9089. [CrossRef] [PubMed]

46. Nussbaum, C.; Bannenberg, S.; Keul, P.; Graler, M.H.; Goncalves-de-Albuquerque, C.F.; Korhonen, H.; von Wnuck Lipinski, K.; Heusch, G.; de Castro Faria Neto, H.C.; Rohwedder, I.; et al. Sphingosine-1-phosphate receptor 3 promotes leukocyte rolling by mobilizing endothelial P-selectin. Nat. Commun. 2015, 6, 6416. [CrossRef] [PubMed]

47. Bascunana, P.; Mohle, L.; Brackhan, M.; Pahnke, J. Fingolimod as a Treatment in Neurologic Disorders Beyond Multiple Sclerosis. Drugs RED 2020, 20, 197-207. [CrossRef]

48. Noda, H.; Takeuchi, H.; Mizuno, T.; Suzumura, A. Fingolimod phosphate promotes the neuroprotective effects of microglia. J. Neuroimmunol. 2013, 256, 13-18. [CrossRef] [PubMed]

49. Jackson, S.J.; Giovannoni, G.; Baker, D. Fingolimod modulates microglial activation to augment markers of remyelination. J. Neuroinflamm. 2011, 8, 76. [CrossRef] [PubMed]

50. Cipriani, R.; Chara, J.C.; Rodriguez-Antiguedad, A.; Matute, C. FTY720 attenuates excitotoxicity and neuroinflammation. J. Neuroinflamm. 2015, 12, 86. [CrossRef] [PubMed]

51. Guo, Y.; Gan, X.; Zhou, H.; Zhou, H.; Pu, S.; Long, X.; Ren, C.; Feng, T.; Tang, H. Fingolimod suppressed the chronic unpredictable mild stress-induced depressive-like behaviors via affecting microglial and NLRP3 inflammasome activation. Life Sci. 2020, 263, 118582. [CrossRef] [PubMed]

52. Gustin, A.; Kirchmeyer, M.; Koncina, E.; Felten, P.; Losciuto, S.; Heurtaux, T.; Tardivel, A.; Heuschling, P.; Dostert, C. NLRP3 Inflammasome Is Expressed and Functional in Mouse Brain Microglia but Not in Astrocytes. PLoS ONE 2015, 10, e0130624. [CrossRef] [PubMed]

53. Sanna, M.G.; Liao, J.; Jo, E.; Alfonso, C.; Ahn, M.Y.; Peterson, M.S.; Webb, B.; Lefebvre, S.; Chun, J.; Gray, N.; et al. Sphingosine 1-phosphate (S1P) receptor subtypes S1P1 and S1P3, respectively, regulate lymphocyte recirculation and heart rate. J. Biol. Chem. 2004, 279, 13839-13848. [CrossRef]

54. Pepin, E.; Jalinier, T.; Lemieux, G.L.; Massicotte, G.; Cyr, M. Sphingosine-1-Phosphate Receptors Modulators Decrease Signs of Neuroinflammation and Prevent Parkinson's Disease Symptoms in the 1-Methyl-4-Phenyl-1,2,3,6-Tetrahydropyridine Mouse Model. Front. Pharmacol. 2020, 11, 77. [CrossRef]

55. Ji, J.; Wang, J.; Yang, J.; Wang, X.P.; Huang, J.J.; Xue, T.F.; Sun, X.L. The Intra-nuclear SphK2-S1P Axis Facilitates M1-to-M2 Shift of Microglia via Suppressing HDAC1-Mediated KLF4 Deacetylation. Front. Immunol. 2019, 10, 1241. [CrossRef]

56. Das, A.; Arifuzzaman, S.; Kim, S.H.; Lee, Y.S.; Jung, K.H.; Chai, Y.G. FTY720 (fingolimod) regulates key target genes essential for inflammation in microglial cells as defined by high-resolution mRNA sequencing. Neuropharmacology 2017, 119, 1-14. [CrossRef]

57. Aytan, N.; Choi, J.K.; Carreras, I.; Brinkmann, V.; Kowall, N.W.; Jenkins, B.G.; Dedeoglu, A. Fingolimod modulates multiple neuroinflammatory markers in a mouse model of Alzheimer's disease. Sci. Rep. 2016, 6, 24939. [CrossRef]

58. Serdar, M.; Herz, J.; Kempe, K.; Lumpe, K.; Reinboth, B.S.; Sizonenko, S.V.; Hou, X.; Herrmann, R.; Hadamitzky, M.; Heumann, R.; et al. Fingolimod protects against neonatal white matter damage and long-term cognitive deficits caused by hyperoxia. Brain Behav. Immun. 2016, 52, 106-119. [CrossRef] 
59. Bechet, S.; O'Sullivan, S.A.; Yssel, J.; Fagan, S.G.; Dev, K.K. Fingolimod Rescues Demyelination in a Mouse Model of Krabbe's Disease. J. Neurosci. 2020, 40, 3104-3118. [CrossRef]

60. Wang, Z.; Kawabori, M.; Houkin, K. FTY720 (Fingolimod) Ameliorates Brain Injury through Multiple Mechanisms and is a Strong Candidate for Stroke Treatment. Curr. Med. Chem. 2020, 27, 2979-2993. [CrossRef]

61. Constantinescu, C.S.; Farooqi, N.; O'Brien, K.; Gran, B. Experimental autoimmune encephalomyelitis (EAE) as a model for multiple sclerosis (MS). Br. J. Pharmacol. 2011, 164, 1079-1106. [CrossRef]

62. Burrows, D.J.; McGown, A.; Jain, S.A.; De Felice, M.; Ramesh, T.M.; Sharrack, B.; Majid, A. Animal models of multiple sclerosis: From rodents to zebrafish. Mult. Scler. 2019, 25, 306-324. [CrossRef] [PubMed]

63. Scott, F.L.; Clemons, B.; Brooks, J.; Brahmachary, E.; Powell, R.; Dedman, H.; Desale, H.G.; Timony, G.A.; Martinborough, E.; Rosen, H.; et al. Ozanimod (RPC1063) is a potent sphingosine-1-phosphate receptor-1 (S1P1) and receptor-5 (S1P5) agonist with autoimmune disease-modifying activity. Br. J. Pharmacol. 2016, 173, 1778-1792. [CrossRef]

64. Musella, A.; Gentile, A.; Guadalupi, L.; Rizzo, F.R.; De Vito, F.; Fresegna, D.; Bruno, A.; Dolcetti, E.; Vanni, V.; Vitiello, L.; et al. Central Modulation of Selective Sphingosine-1-Phosphate Receptor 1 Ameliorates Experimental Multiple Sclerosis. Cells 2020, 9, 1290. [CrossRef] [PubMed]

65. Behrangi, N.; Fischbach, F.; Kipp, M. Mechanism of Siponimod: Anti-Inflammatory and Neuroprotective Mode of Action. Cells 2019, 8, 24. [CrossRef]

66. Ward, L.A.; Lee, D.S.; Sharma, A.; Wang, A.; Naouar, I.; Ma, X.I.; Pikor, N.; Nuesslein-Hildesheim, B.; Ramaglia, V.; Gommerman, J.L. Siponimod therapy implicates Th17 cells in a preclinical model of subpial cortical injury. JCI Insight. 2020, 5. [CrossRef] [PubMed]

67. Cahalan, S.M.; Gonzalez-Cabrera, P.J.; Sarkisyan, G.; Nguyen, N.; Schaeffer, M.T.; Huang, L.; Yeager, A.; Clemons, B.; Scott, F.; Rosen, H. Actions of a picomolar short-acting S1P(1) agonist in S1P(1)-eGFP knock-in mice. Nat. Chem. Biol. 2011, 7, 254-256. [CrossRef]

68. Li, R.; Venkat, P.; Chopp, M.; Zhang, Q.; Yan, T.; Chen, J. RP001 hydrochloride improves neurological outcome after subarachnoid hemorrhage. J. Neurol. Sci. 2019, 399, 6-14. [CrossRef]

69. Asle-Rousta, M.; Kolahdooz, Z.; Dargahi, L.; Ahmadiani, A.; Nasoohi, S. Prominence of central sphingosine-1-phosphate receptor-1 in attenuating abeta-induced injury by fingolimod. J. Mol. Neurosci. 2014, 54, 698-703. [CrossRef]

70. Carreras, I.; Aytan, N.; Choi, J.K.; Tognoni, C.M.; Kowall, N.W.; Jenkins, B.G.; Dedeoglu, A. Dual dose-dependent effects of fingolimod in a mouse model of Alzheimer's disease. Sci. Rep. 2019, 9, 10972. [CrossRef]

71. Sawano, T.; Watanabe, F.; Ishiguchi, M.; Doe, N.; Furuyama, T.; Inagaki, S. Effect of Sema4D on microglial function in middle cerebral artery occlusion mice. Glia 2015, 63, 2249-2259. [CrossRef]

72. Tam, W.Y.; Ma, C.H. Bipolar/rod-shaped microglia are proliferating microglia with distinct M1/M2 phenotypes. Sci. Rep. 2014, 4, 7279. [CrossRef]

73. Kartalou, G.I.; Salgueiro-Pereira, A.R.; Endres, T.; Lesnikova, A.; Casarotto, P.; Pousinha, P.; Delanoe, K.; Edelmann, E.; Castren, E.; Gottmann, K.; et al. Anti-Inflammatory Treatment with FTY720 Starting after Onset of Symptoms Reverses Synaptic Deficits in an AD Mouse Model. Int. J. Mol. Sci. 2020, 21, 8957. [CrossRef]

74. McManus, R.M.; Finucane, O.M.; Wilk, M.M.; Mills, K.H.G.; Lynch, M.A. FTY720 Attenuates Infection-Induced Enhancement of Abeta Accumulation in APP/PS1 Mice by Modulating Astrocytic Activation. J. Neuroimmune Pharmacol. 2017, 12, 670-681. [CrossRef]

75. Ren, M.; Han, M.; Wei, X.; Guo, Y.; Shi, H.; Zhang, X.; Perez, R.G.; Lou, H. FTY720 Attenuates 6-OHDA-Associated Dopaminergic Degeneration in Cellular and Mouse Parkinsonian Models. Neurochem. Res. 2017, 42, 686-696. [CrossRef] [PubMed]

76. Yao, S.; Li, L.; Sun, X.; Hua, J.; Zhang, K.; Hao, L.; Liu, L.; Shi, D.; Zhou, H. FTY720 Inhibits MPP(+)-Induced Microglial Activation by Affecting NLRP3 Inflammasome Activation. J. Neuroimmune Pharm. 2019, 14, 478-492. [CrossRef]

77. Gaire, B.P.; Lee, C.H.; Sapkota, A.; Lee, S.Y.; Chun, J.; Cho, H.J.; Nam, T.G.; Choi, J.W. Identification of Sphingosine 1-Phosphate Receptor Subtype 1 (S1P1) as a Pathogenic Factor in Transient Focal Cerebral Ischemia. Mol. Neurobiol. 2018, 55, $2320-2332$. [CrossRef]

78. Gaire, B.P.; Bae, Y.J.; Choi, J.W. S1P1 Regulates M1/M2 Polarization toward Brain Injury after Transient Focal Cerebral Ischemia. Biomol. Ther. 2019, 522-529. [CrossRef] [PubMed]

79. Jayaraj, R.L.; Azimullah, S.; Beiram, R.; Jalal, F.Y.; Rosenberg, G.A. Neuroinflammation: Friend and foe for ischemic stroke. J. Neuroinflamm. 2019, 16, 142. [CrossRef]

80. Kunz, A.; Abe, T.; Hochrainer, K.; Shimamura, M.; Anrather, J.; Racchumi, G.; Zhou, P.; Iadecola, C. Nuclear factor-kappaB activation and postischemic inflammation are suppressed in CD36-null mice after middle cerebral artery occlusion. J. Neurosci. 2008, 28, 1649-1658. [CrossRef]

81. Xie, W.; Zhu, T.; Dong, X.; Nan, F.; Meng, X.; Zhou, P.; Sun, G.; Sun, X. HMGB1-triggered inflammation inhibition of notoginseng leaf triterpenes against cerebral ischemia and reperfusion injury via MAPK and NF-kappaB signaling pathways. Biomolecules 2019, 9, 512. [CrossRef] [PubMed]

82. Gonzalez-Cabrera, P.J.; Cahalan, S.M.; Nguyen, N.; Sarkisyan, G.; Leaf, N.B.; Cameron, M.D.; Kago, T.; Rosen, H. S1P(1) receptor modulation with cyclical recovery from lymphopenia ameliorates mouse model of multiple sclerosis. Mol. Pharmacol. 2012, 81, 166-174. [CrossRef] [PubMed] 
83. Kim, S.; Bielawski, J.; Yang, H.; Kong, Y.; Zhou, B.; Li, J. Functional antagonism of sphingosine-1-phosphate receptor 1 prevents cuprizone-induced demyelination. Glia 2018, 66, 654-669. [CrossRef]

84. Rothhammer, V.; Kenison, J.E.; Tjon, E.; Takenaka, M.C.; de Lima, K.A.; Borucki, D.M.; Chao, C.C.; Wilz, A.; Blain, M.; Healy, L.; et al. Sphingosine 1-phosphate receptor modulation suppresses pathogenic astrocyte activation and chronic progressive $\mathrm{CNS}$ inflammation. Proc. Natl. Acad. Sci. USA 2017, 114, 2012-2017. [CrossRef] [PubMed]

85. Oveland, E.; Ahmad, I.; Lereim, R.R.; Kroksveen, A.C.; Barsnes, H.; Guldbrandsen, A.; Myhr, K.M.; Bo, L.; Berven, F.S.; Wergeland, S. Cuprizone and EAE mouse frontal cortex proteomics revealed proteins altered in multiple sclerosis. Sci. Rep. 2021, 11, 7174. [CrossRef]

86. Hillis, J.M.; Davies, J.; Mundim, M.V.; Al-Dalahmah, O.; Szele, F.G. Cuprizone demyelination induces a unique inflammatory response in the subventricular zone. J. Neuroinflamm. 2016, 13, 190. [CrossRef] [PubMed]

87. Sapkota, A.; Gaire, B.P.; Kang, M.G.; Choi, J.W. S1P2 contributes to microglial activation and M1 polarization following cerebral ischemia through ERK1/2 and JNK. Sci. Rep. 2019, 9, 12106. [CrossRef]

88. Sanchez, T.; Skoura, A.; Wu, M.T.; Casserly, B.; Harrington, E.O.; Hla, T. Induction of vascular permeability by the sphingosine-1phosphate receptor-2 (S1P2R) and its downstream effectors ROCK and PTEN. Arterioscler. Thromb. Vasc. Biol. 2007, 27, 1312-1318. [CrossRef]

89. Arikawa, K.; Takuwa, N.; Yamaguchi, H.; Sugimoto, N.; Kitayama, J.; Nagawa, H.; Takehara, K.; Takuwa, Y. Ligand-dependent inhibition of B16 melanoma cell migration and invasion via endogenous S1P2 G protein-coupled receptor. Requirement of inhibition of cellular RAC activity. J. Biol. Chem. 2003, 278, 32841-32851. [CrossRef]

90. Kim, G.S.; Yang, L.; Zhang, G.; Zhao, H.; Selim, M.; McCullough, L.D.; Kluk, M.J.; Sanchez, T. Critical role of sphingosine-1phosphate receptor-2 in the disruption of cerebrovascular integrity in experimental stroke. Nat. Commun. 2015, 6, 7893. [CrossRef]

91. Shirakawa, H.; Katsumoto, R.; Iida, S.; Miyake, T.; Higuchi, T.; Nagashima, T.; Nagayasu, K.; Nakagawa, T.; Kaneko, S. Sphingosine-1-phosphate induces $\mathrm{Ca}(2+)$ signaling and CXCL1 release via TRPC6 channel in astrocytes. Glia 2017, 65, 1005-1016. [CrossRef]

92. Li, C.; Li, J.N.; Kays, J.; Guerrero, M.; Nicol, G.D. Sphingosine 1-phosphate enhances the excitability of rat sensory neurons through activation of sphingosine 1-phosphate receptors 1 and/or 3. J. Neuroinflamm. 2015, 12, 70. [CrossRef]

93. Tang, H.B.; Jiang, X.J.; Wang, C.; Liu, S.C. S1P/S1PR3 signaling mediated proliferation of pericytes via Ras/pERK pathway and CAY10444 had beneficial effects on spinal cord injury. Biochem. Biophys. Res. Commun. 2018, 498, 830-836. [CrossRef]

94. Gaire, B.P.; Song, M.R.; Choi, J.W. Sphingosine 1-phosphate receptor subtype 3 (S1P3) contributes to brain injury after transient focal cerebral ischemia via modulating microglial activation and their M1 polarization. J. Neuroinflamm. 2018, 15, 284. [CrossRef]

95. Groves, A.; Kihara, Y.; Chun, J. Fingolimod: Direct CNS effects of sphingosine 1-phosphate (S1P) receptor modulation and implications in multiple sclerosis therapy. J. Neurol. Sci. 2013, 328, 9-18. [CrossRef] [PubMed]

96. Graeler, M.; Goetzl, E.J. Activation-regulated expression and chemotactic function of sphingosine 1-phosphate receptors in mouse splenic T cells. FASEB J. 2002, 16, 1874-1878. [CrossRef] [PubMed]

97. Fettel, J.; Kuhn, B.; Guillen, N.A.; Surun, D.; Peters, M.; Bauer, R.; Angioni, C.; Geisslinger, G.; Schnutgen, F.; Meyer Zu Heringdorf, D.; et al. Sphingosine-1-phosphate (S1P) induces potent anti-inflammatory effects in vitro and in vivo by S1P receptor 4-mediated suppression of 5-lipoxygenase activity. FASEB J. 2019, 33, 1711-1726. [CrossRef] [PubMed]

98. Allende, M.L.; Bektas, M.; Lee, B.G.; Bonifacino, E.; Kang, J.; Tuymetova, G.; Chen, W.; Saba, J.D.; Proia, R.L. Sphingosine-1phosphate lyase deficiency produces a pro-inflammatory response while impairing neutrophil trafficking. J. Biol. Chem. 2011, 286, 7348-7358. [CrossRef]

99. Salas-Perdomo, A.; Miro-Mur, F.; Gallizioli, M.; Brait, V.H.; Justicia, C.; Meissner, A.; Urra, X.; Chamorro, A.; Planas, A.M. Role of the S1P pathway and inhibition by fingolimod in preventing hemorrhagic transformation after stroke. Sci. Rep. 2019, 9, 8309. [CrossRef]

100. Foster, C.A.; Mechtcheriakova, D.; Storch, M.K.; Balatoni, B.; Howard, L.M.; Bornancin, F.; Wlachos, A.; Sobanov, J.; Kinnunen, A.; Baumruker, T. FTY720 rescue therapy in the dark agouti rat model of experimental autoimmune encephalomyelitis: Expression of central nervous system genes and reversal of blood-brain-barrier damage. Brain Pathol. 2009, 19, 254-266. [CrossRef]

101. Tham, C.S.; Lin, F.F.; Rao, T.S.; Yu, N.; Webb, M. Microglial activation state and lysophospholipid acid receptor expression. Int. J. Dev. Neurosci. 2003, 21, 431-443. [CrossRef]

102. Miron, V.E.; Ludwin, S.K.; Darlington, P.J.; Jarjour, A.A.; Soliven, B.; Kennedy, T.E.; Antel, J.P. Fingolimod (FTY720) enhances remyelination following demyelination of organotypic cerebellar slices. Am. J. Pathol. 2010, 176, 2682-2694. [CrossRef] [PubMed]

103. Jonnalagadda, D.; Sunkara, M.; Morris, A.J.; Whiteheart, S.W. Granule-mediated release of sphingosine-1-phosphate by activated platelets. Biochim. Biophys. Acta 2014, 1841, 1581-1589. [CrossRef] [PubMed]

104. Weth, D.; Benetti, C.; Rauch, C.; Gstraunthaler, G.; Schmidt, H.; Geisslinger, G.; Sabbadini, R.; Proia, R.L.; Kress, M. Activated platelets release sphingosine 1-phosphate and induce hypersensitivity to noxious heat stimuli in vivo. Front. Neurosci. 2015, 9, 140. [CrossRef] [PubMed]

105. Anelli, V.; Bassi, R.; Tettamanti, G.; Viani, P.; Riboni, L. Extracellular release of newly synthesized sphingosine-1-phosphate by cerebellar granule cells and astrocytes. J. Neurochem. 2005, 92, 1204-1215. [CrossRef]

106. Bassi, R.; Anelli, V.; Giussani, P.; Tettamanti, G.; Viani, P.; Riboni, L. Sphingosine-1-phosphate is released by cerebellar astrocytes in response to bFGF and induces astrocyte proliferation through Gi-protein-coupled receptors. Glia 2006, 53, 621-630. [CrossRef] 
107. Kimura, A.; Ohmori, T.; Ohkawa, R.; Madoiwa, S.; Mimuro, J.; Murakami, T.; Kobayashi, E.; Hoshino, Y.; Yatomi, Y.; Sakata, Y. Essential roles of sphingosine 1-phosphate/S1P1 receptor axis in the migration of neural stem cells toward a site of spinal cord injury. Stem. Cells 2007, 25, 115-124. [CrossRef]

108. Fischer, I.; Alliod, C.; Martinier, N.; Newcombe, J.; Brana, C.; Pouly, S. Sphingosine kinase 1 and sphingosine 1-phosphate receptor 3 are functionally upregulated on astrocytes under pro-inflammatory conditions. PLoS ONE 2011, 6, e23905. [CrossRef]

109. Sanada, Y.; Mizushima, T.; Kai, Y.; Nishimura, J.; Hagiya, H.; Kurata, H.; Mizuno, H.; Uejima, E.; Ito, T. Therapeutic effects of novel sphingosine-1-phosphate receptor agonist W-061 in murine DSS colitis. PLoS ONE 2011, 6, e23933. [CrossRef] [PubMed]

110. Volpi, C.; Orabona, C.; Macchiarulo, A.; Bianchi, R.; Puccetti, P.; Grohmann, U. Preclinical discovery and development of fingolimod for the treatment of multiple sclerosis. Expert. Opin. Drug. Discov. 2019, 14, 1199-1212. [CrossRef]

111. Sorensen, S.D.; Nicole, O.; Peavy, R.D.; Montoya, L.M.; Lee, C.J.; Murphy, T.J.; Traynelis, S.F.; Hepler, J.R. Common signaling pathways link activation of murine PAR-1, LPA, and S1P receptors to proliferation of astrocytes. Mol. Pharmacol. 2003, 64, 1199-1209. [CrossRef]

112. Rao, T.S.; Lariosa-Willingham, K.D.; Lin, F.F.; Palfreyman, E.L.; Yu, N.; Chun, J.; Webb, M. Pharmacological characterization of lysophospholipid receptor signal transduction pathways in rat cerebrocortical astrocytes. Brain Res. 2003, 990, 182-194. [CrossRef]

113. Rao, T.S.; Lariosa-Willingham, K.D.; Lin, F.F.; Yu, N.; Tham, C.S.; Chun, J.; Webb, M. Growth factor pre-treatment differentially regulates phosphoinositide turnover downstream of lysophospholipid receptor and metabotropic glutamate receptors in cultured rat cerebrocortical astrocytes. Int. J. Dev. Neurosci. 2004, 22, 131-135. [CrossRef]

114. Giovannoni, F.; Quintana, F.J. The Role of Astrocytes in CNS Inflammation. Trends Immunol. 2020, 41, 805-819. [CrossRef] [PubMed]

115. Linnerbauer, M.; Wheeler, M.A.; Quintana, F.J. Astrocyte Crosstalk in CNS Inflammation. Neuron 2020, 108, 608-622. [CrossRef]

116. Farez, M.F.; Correale, J. Sphingosine 1-phosphate signaling in astrocytes: Implications for progressive multiple sclerosis. J. Neurol. Sci. 2016, 361, 60-65. [CrossRef]

117. Van Doorn, R.; Van Horssen, J.; Verzijl, D.; Witte, M.; Ronken, E.; Van Het Hof, B.; Lakeman, K.; Dijkstra, C.D.; Van Der Valk, P.; Reijerkerk, A.; et al. Sphingosine 1-phosphate receptor 1 and 3 are upregulated in multiple sclerosis lesions. Glia 2010, 58, 1465-1476. [CrossRef]

118. Brana, C.; Frossard, M.J.; Pescini Gobert, R.; Martinier, N.; Boschert, U.; Seabrook, T.J. Immunohistochemical detection of sphingosine-1-phosphate receptor 1 and 5 in human multiple sclerosis lesions. Neuropathol. Appl. Neurobiol. 2014, 40, 564-578. [CrossRef] [PubMed]

119. Cohen, J.A.; Chun, J. Mechanisms of fingolimod's efficacy and adverse effects in multiple sclerosis. Ann. Neurol. 2011, 69, 759-777. [CrossRef]

120. Hunter, S.F.; Bowen, J.D.; Reder, A.T. The Direct Effects of Fingolimod in the Central Nervous System: Implications for Relapsing Multiple Sclerosis. CNS Drugs 2016, 30, 135-147. [CrossRef]

121. Wang, J.; Wang, J.; Lu, P.; Cai, Y.; Wang, Y.; Hong, L.; Ren, H.; Heng, B.C.; Liu, H.; Zhou, J.; et al. Local delivery of FTY720 in PCL membrane improves SCI functional recovery by reducing reactive astrogliosis. Biomaterials 2015, 62, 76-87. [CrossRef] [PubMed]

122. Cruz, V.T.; Fonseca, J. Central effects of fingolimod. Rev. Neurol. 2014, 59, 121-128.

123. Cheng, W.; Chen, G. Chemokines and chemokine receptors in multiple sclerosis. Mediat. Inflamm. 2014, 2014, 659206. [CrossRef]

124. Ponath, G.; Park, C.; Pitt, D. The Role of Astrocytes in Multiple Sclerosis. Front. Immunol. 2018, 9, 217. [CrossRef]

125. Bjelobaba, I.; Savic, D.; Lavrnja, I. Multiple Sclerosis and Neuroinflammation: The Overview of Current and Prospective Therapies. Curr. Pharm. Des. 2017, 23, 693-730. [CrossRef] [PubMed]

126. Colombo, E.; Di Dario, M.; Capitolo, E.; Chaabane, L.; Newcombe, J.; Martino, G.; Farina, C. Fingolimod may support neuroprotection via blockade of astrocyte nitric oxide. Ann. Neurol. 2014, 76, 325-337. [CrossRef]

127. Brinkmann, V. FTY720 (fingolimod) in Multiple Sclerosis: Therapeutic effects in the immune and the central nervous system. Br. J. Pharmacol. 2009, 158, 1173-1182. [CrossRef] [PubMed]

128. Ma, W.; Zhang, M.; Liu, S.; Wang, M.; Shi, Y.; Yang, T.; Li, X.; Zhu, L. Matrine alleviates astrogliosis through sphingosine 1-phosphate signaling in experimental autoimmune encephalomyelitis. Neurosci. Lett. 2020, 715, 134599. [CrossRef]

129. Osinde, M.; Mullershausen, F.; Dev, K.K. Phosphorylated FTY720 stimulates ERK phosphorylation in astrocytes via S1P receptors. Neuropharmacology 2007, 52, 1210-1218. [CrossRef] [PubMed]

130. Lu, N.; Malemud, C.J. Extracellular Signal-Regulated Kinase: A Regulator of Cell Growth, Inflammation, Chondrocyte and Bone Cell Receptor-Mediated Gene Expression. Int. J. Mol. Sci. 2019, 20, 3792. [CrossRef]

131. Sun, J.; Nan, G. The extracellular signal-regulated kinase $1 / 2$ pathway in neurological diseases: A potential therapeutic target (Review). Int. J. Mol. Med. 2017, 39, 1338-1346. [CrossRef] [PubMed]

132. Okazaki, R.; Doi, T.; Hayakawa, K.; Morioka, K.; Imamura, O.; Takishima, K.; Hamanoue, M.; Sawada, Y.; Nagao, M.; Tanaka, S.; et al. The crucial role of Erk2 in demyelinating inflammation in the central nervous system. J. Neuroinflamm. 2016, 13, 235. [CrossRef]

133. Colombo, E.; Bassani, C.; De Angelis, A.; Ruffini, F.; Ottoboni, L.; Comi, G.; Martino, G.; Farina, C. Siponimod (BAF312) Activates Nrf2 While Hampering NFkappaB in Human Astrocytes, and Protects From Astrocyte-Induced Neurodegeneration. Front. Immunol. 2020, 11, 635. [CrossRef] [PubMed]

134. Vomund, S.; Schafer, A.; Parnham, M.J.; Brune, B.; von Knethen, A. Nrf2, the Master Regulator of Anti-Oxidative Responses. Int. J. Mol. Sci. 2017, 18, 2772. [CrossRef] [PubMed] 
135. O'Sullivan, C.; Schubart, A.; Mir, A.K.; Dev, K.K. The dual S1PR1/S1PR5 drug BAF312 (Siponimod) attenuates demyelination in organotypic slice cultures. J. Neuroinflamm. 2016, 13, 31. [CrossRef] [PubMed]

136. Norimatsu, Y.; Ohmori, T.; Kimura, A.; Madoiwa, S.; Mimuro, J.; Seichi, A.; Yatomi, Y.; Hoshino, Y.; Sakata, Y. FTY720 improves functional recovery after spinal cord injury by primarily nonimmunomodulatory mechanisms. Am. J. Pathol. 2012, 180, 1625-1635. [CrossRef]

137. Dusaban, S.S.; Chun, J.; Rosen, H.; Purcell, N.H.; Brown, J.H. Sphingosine 1-phosphate receptor 3 and RhoA signaling mediate inflammatory gene expression in astrocytes. J. Neuroinflamm. 2017, 14, 111. [CrossRef]

138. Ferrer, M.D.; Busquets-Cortes, C.; Capo, X.; Tejada, S.; Tur, J.A.; Pons, A.; Sureda, A. Cyclooxygenase-2 Inhibitors as a Therapeutic Target in Inflammatory Diseases. Curr. Med. Chem. 2019, 26, 3225-3241. [CrossRef]

139. Janssen, S.; Schlegel, C.; Gudi, V.; Prajeeth, C.K.; Skripuletz, T.; Trebst, C.; Stangel, M. Effect of FTY720-phosphate on the expression of inflammation-associated molecules in astrocytes in vitro. Mol. Med. Rep. 2015, 12, 6171-6177. [CrossRef]

140. Conductier, G.; Blondeau, N.; Guyon, A.; Nahon, J.L.; Rovere, C. The role of monocyte chemoattractant protein MCP1/CCL2 in neuroinflammatory diseases. J. Neuroimmunol. 2010, 224, 93-100. [CrossRef] [PubMed]

141. Ogawa, Y.; Sano, T.; Irisa, M.; Kodama, T.; Saito, T.; Furusawa, E.; Kaizu, K.; Yanagi, Y.; Tsukimura, T.; Togawa, T.; et al. FcRgamma-dependent immune activation initiates astrogliosis during the asymptomatic phase of Sandhoff disease model mice. Sci. Rep. 2017, 7, 40518. [CrossRef]

142. Wu, Y.P.; Mizugishi, K.; Bektas, M.; Sandhoff, R.; Proia, R.L. Sphingosine kinase 1/S1P receptor signaling axis controls glial proliferation in mice with Sandhoff disease. Hum. Mol. Genet. 2008, 17, 2257-2264. [CrossRef] [PubMed]

143. Gril, B.; Paranjape, A.N.; Woditschka, S.; Hua, E.; Dolan, E.L.; Hanson, J.; Wu, X.; Kloc, W.; Izycka-Swieszewska, E.; Duchnowska, R.; et al. Reactive astrocytic S1P3 signaling modulates the blood-tumor barrier in brain metastases. Nat. Commun. 2018, 9, 2705. [CrossRef]

144. Mustaly-Kalimi, S.; Littlefield, A.M.; Stutzmann, G.E. Calcium Signaling Deficits in Glia and Autophagic Pathways Contributing to Neurodegenerative Disease. Antioxid Redox Signal. 2018, 29, 1158-1175. [CrossRef]

145. Yu, Z.; Dou, F.; Wang, Y.; Hou, L.; Chen, H. Ca(2+)-dependent endoplasmic reticulum stress correlation with astrogliosis involves upregulation of KCa3.1 and inhibition of AKT/mTOR signaling. J. Neuroinflamm. 2018, 15, 316. [CrossRef] [PubMed]

146. Zhang, Y.; Li, X.; Ciric, B.; Ma, C.G.; Gran, B.; Rostami, A.; Zhang, G.X. Effect of Fingolimod on Neural Stem Cells: A Novel Mechanism and Broadened Application for Neural Repair. Mol. Ther. 2017, 25, 401-415. [CrossRef] [PubMed]

147. Mutoh, T.; Rivera, R.; Chun, J. Insights into the pharmacological relevance of lysophospholipid receptors. Br. J. Pharmacol. 2012, 165, 829-844. [CrossRef]

148. Karunakaran, I.; van Echten-Deckert, G. Sphingosine 1-phosphate-A double edged sword in the brain. Biochim. Biophys. Acta Biomembr. 2017, 1859, 1573-1582. [CrossRef]

149. Bernhart, E.; Kollroser, M.; Rechberger, G.; Reicher, H.; Heinemann, A.; Schratl, P.; Hallstrom, S.; Wintersperger, A.; Nusshold, C.; DeVaney, T.; et al. Lysophosphatidic acid receptor activation affects the $\mathrm{C} 13 \mathrm{NJ}$ microglia cell line proteome leading to alterations in glycolysis, motility, and cytoskeletal architecture. Proteomics 2010, 10, 141-158. [CrossRef]

150. Fujita, R.; Ma, Y.; Ueda, H. Lysophosphatidic acid-induced membrane ruffling and brain-derived neurotrophic factor gene expression are mediated by ATP release in primary microglia. J. Neurochem. 2008, 107, 152-160. [CrossRef]

151. Plastira, I.; Bernhart, E.; Joshi, L.; Koyani, C.N.; Strohmaier, H.; Reicher, H.; Malle, E.; Sattler, W. MAPK signaling determines lysophosphatidic acid (LPA)-induced inflammation in microglia. J. Neuroinflamm. 2020, 17, 127. [CrossRef]

152. Plastira, I.; Bernhart, E.; Goeritzer, M.; Reicher, H.; Kumble, V.B.; Kogelnik, N.; Wintersperger, A.; Hammer, A.; Schlager, S.; Jandl, K.; et al. 1-Oleyl-lysophosphatidic acid (LPA) promotes polarization of BV-2 and primary murine microglia towards an M1-like phenotype. J. Neuroinflamm. 2016, 13, 205. [CrossRef] [PubMed]

153. Uchida, H.; Matsumoto, M.; Ueda, H. Profiling of BoNT/C3-reversible gene expression induced by lysophosphatidic acid: ephrinB1 gene up-regulation underlying neuropathic hyperalgesia and allodynia. Neurochem. Int. 2009, 54, 215-221. [CrossRef] [PubMed]

154. Ma, L.; Nagai, J.; Ueda, H. Microglial activation mediates de novo lysophosphatidic acid production in a model of neuropathic pain. J. Neurochem. 2010, 115, 643-653. [CrossRef] [PubMed]

155. Ledeboer, A.; Sloane, E.M.; Milligan, E.D.; Frank, M.G.; Mahony, J.H.; Maier, S.F.; Watkins, L.R. Minocycline attenuates mechanical allodynia and proinflammatory cytokine expression in rat models of pain facilitation. Pain 2005, 115, 71-83. [CrossRef] [PubMed]

156. Ueda, H. Lysophosphatidic acid as the initiator of neuropathic pain. Biol. Pharm. Bull. 2011, 34, 1154-1158. [CrossRef] [PubMed]

157. Ueda, H.; Ueda, M. Lysophosphatidic acid as an initiator of neuropathic pain: Biosynthesis and demyelination. Clin. Lipidol. 2011, 6, 147-158. [CrossRef]

158. Kwon, J.H.; Gaire, B.P.; Park, S.J.; Shin, D.Y.; Choi, J.W. Identifying lysophosphatidic acid receptor subtype 1 (LPA1) as a novel factor to modulate microglial activation and their TNF-alpha production by activating ERK1/2. Biochim. Biophys. Acta Mol. Cell Biol. Lipids 2018, 1863, 1237-1245. [CrossRef]

159. Amaral, R.F.; Geraldo, L.H.M.; Einicker-Lamas, M.; TCLS, E.S.; Mendes, F.; Lima, F.R.S. Microglial lysophosphatidic acid promotes glioblastoma proliferation and migration via LPA1 receptor. J. Neurochem. 2021, 156, 499-512. [CrossRef]

160. Gaire, B.P.; Sapkota, A.; Choi, J.W. BMS-986020, a Specific LPA1 Antagonist, Provides Neuroprotection against Ischemic Stroke in Mice. Antioxidants 2020, 9, 1097. [CrossRef] [PubMed] 
161. Lee, C.H.; Sapkota, A.; Gaire, B.P.; Choi, J.W. NLRP3 Inflammasome Activation Is Involved in LPA1-Mediated Brain Injury after Transient Focal Cerebral Ischemia. Int. J. Mol. Sci. 2020, 21, 8595. [CrossRef] [PubMed]

162. Gaire, B.P.; Sapkota, A.; Song, M.R.; Choi, J.W. Lysophosphatidic acid receptor 1 (LPA1) plays critical roles in microglial activation and brain damage after transient focal cerebral ischemia. J. Neuroinflamm. 2019, 16, 170. [CrossRef]

163. Kihara, Y.; Mizuno, H.; Chun, J. Lysophospholipid receptors in drug discovery. Exp. Cell. Res. 2015, 333, 171-177. [CrossRef]

164. Smith, M.J.; Lawler, M.J.; Kopp, N.; Mcleod, D.D.; Davulcu, A.H.; Lin, D.; Katipally, K.; Sfouggatakis, C. Development of a Concise Multikilogram Synthesis of LPA-1 Antagonist BMS-986020 via a Tandem Borylation-Suzuki Procedure. Org. Process. Res. Dev. 2017, 21, 1859-1863. [CrossRef]

165. Pena, A.; kim, J.; Donnelly, D.; Murphy, B.; Shuster, D.; Watson, L.; Bonacorsi, S.; Hayes, W.; Chow, P.; Du, S. Autoradiographic evaluation of [18F]BMT-083133, a lysophosphatidic acid receptor 1 (LPA1) radioligand. J. Nucl. Med. 2014, 55, 1207.

166. Gao, L.; Shi, H.; Sherchan, P.; Tang, H.; Peng, L.; Xie, S.; Liu, R.; Hu, X.; Tang, J.; Xia, Y.; et al. Inhibition of lysophosphatidic acid receptor 1 attenuates neuroinflammation via PGE2/EP2/NOX2 signalling and improves the outcome of intracerebral haemorrhage in mice. Brain Behav. Immun. 2021, 91, 615-626. [CrossRef] [PubMed]

167. Swaney, J.S.; Chapman, C.; Correa, L.D.; Stebbins, K.J.; Bundey, R.A.; Prodanovich, P.C.; Fagan, P.; Baccei, C.S.; Santini, A.M.; Hutchinson, J.H.; et al. A novel, orally active LPA(1) receptor antagonist inhibits lung fibrosis in the mouse bleomycin model. $\mathrm{Br}$. J. Pharmacol. 2010, 160, 1699-1713. [CrossRef] [PubMed]

168. Swaney, J.S.; Chapman, C.; Correa, L.D.; Stebbins, K.J.; Broadhead, A.R.; Bain, G.; Santini, A.M.; Darlington, J.; King, C.D.; Baccei, C.S.; et al. Pharmacokinetic and pharmacodynamic characterization of an oral lysophosphatidic acid type 1 receptorselective antagonist. J. Pharmacol. Exp. Ther. 2011, 336, 693-700. [CrossRef]

169. Rivera, R.R.; Lin, M.E.; Bornhop, E.C.; Chun, J. Conditional Lpar1 gene targeting identifies cell types mediating neuropathic pain. FASEB J. 2020, 34, 8833-8842. [CrossRef]

170. Ueda, H. LPA receptor signaling as a therapeutic target for radical treatment of neuropathic pain and fibromyalgia. Pain Manag. 2020, 10, 43-53. [CrossRef]

171. Xu, L.; Su, J.; Guo, L.; Wang, S.; Deng, X.; Ma, S. Modulation of LPA1 receptor-mediated neuronal apoptosis by Saikosaponin-d: A target involved in depression. Neuropharmacology 2019, 155, 150-161. [CrossRef] [PubMed]

172. Su, J.; Pan, Y.W.; Wang, S.Q.; Li, X.Z.; Huang, F.; Ma, S.P. Saikosaponin-d attenuated lipopolysaccharide-induced depressive-like behaviors via inhibiting microglia activation and neuroinflammation. Int. Immunopharmacol. 2020, 80, 106181. [CrossRef] [PubMed]

173. Lopez-Serrano, C.; Santos-Nogueira, E.; Francos-Quijorna, I.; Coll-Miro, M.; Chun, J.; Lopez-Vales, R. Lysophosphatidic acid receptor type 2 activation contributes to secondary damage after spinal cord injury in mice. Brain Behav. Immun. 2019, 76, 258-267. [CrossRef]

174. Fischer, D.J.; Nusser, N.; Virag, T.; Yokoyama, K.; Wang, D.; Baker, D.L.; Bautista, D.; Parrill, A.L.; Tigyi, G. Short-chain phosphatidates are subtype-selective antagonists of lysophosphatidic acid receptors. Mol. Pharmacol. 2001, 60, 776-784.

175. Ohta, H.; Sato, K.; Murata, N.; Damirin, A.; Malchinkhuu, E.; Kon, J.; Kimura, T.; Tobo, M.; Yamazaki, Y.; Watanabe, T.; et al. Ki16425, a subtype-selective antagonist for EDG-family lysophosphatidic acid receptors. Mol. Pharmacol. 2003, 64, 994-1005. [CrossRef] [PubMed]

176. Awada, R.; Rondeau, P.; Gres, S.; Saulnier-Blache, J.S.; Lefebvre d'Hellencourt, C.; Bourdon, E. Autotaxin protects microglial cells against oxidative stress. Free Radic. Biol. Med. 2012, 52, 516-526. [CrossRef] [PubMed]

177. Kozian, D.H.; von Haeften, E.; Joho, S.; Czechtizky, W.; Anumala, U.R.; Roux, P.; Dudda, A.; Evers, A.; Nazare, M. Modulation of Hexadecyl-LPA-Mediated Activation of Mast Cells and Microglia by a Chemical Probe for LPA5. Chembiochem 2016, 17, 861-865. [CrossRef]

178. Kozian, D.H.; Evers, A.; Florian, P.; Wonerow, P.; Joho, S.; Nazare, M. Selective non-lipid modulator of LPA5 activity in human platelets. Bioorg. Med. Chem. Lett. 2012, 22, 5239-5243. [CrossRef]

179. Sapkota, A.; Lee, C.H.; Park, S.J.; Choi, J.W. Lysophosphatidic Acid Receptor 5 Plays a Pathogenic Role in Brain Damage after Focal Cerebral Ischemia by Modulating Neuroinflammatory Responses. Cells 2020, 9, 1446. [CrossRef]

180. Plastira, I.; Joshi, L.; Bernhart, E.; Schoene, J.; Specker, E.; Nazare, M.; Sattler, W. Small-Molecule Lysophosphatidic Acid Receptor 5 (LPAR5) Antagonists: Versatile Pharmacological Tools to Regulate Inflammatory Signaling in BV-2 Microglia Cells. Front. Cell Neurosci. 2019, 13, 531. [CrossRef]

181. Plastira, I.; Bernhart, E.; Goeritzer, M.; DeVaney, T.; Reicher, H.; Hammer, A.; Lohberger, B.; Wintersperger, A.; Zucol, B.; Graier, W.F.; et al. Lysophosphatidic acid via LPA-receptor 5/protein kinase D-dependent pathways induces a motile and pro-inflammatory microglial phenotype. J. Neuroinflamm. 2017, 14, 253. [CrossRef]

182. Sapkota, A.; Park, S.J.; Choi, J.W. Inhibition of LPA5 Activity Provides Long-Term Neuroprotection in Mice with Brain Ischemic Stroke. Biomol. Ther. 2020, 28, 512-518. [CrossRef] [PubMed]

183. Nakanaga, K.; Hama, K.; Aoki, J. Autotaxin-an LPA producing enzyme with diverse functions. J. Biochem. 2010, 148, 13-24. [CrossRef] [PubMed]

184. Hoelzinger, D.B.; Nakada, M.; Demuth, T.; Rosensteel, T.; Reavie, L.B.; Berens, M.E. Autotaxin: A secreted autocrine/paracrine factor that promotes glioma invasion. J. Neurooncol. 2008, 86, 297-309. [CrossRef]

185. Ramakers, G.J.; Moolenaar, W.H. Regulation of astrocyte morphology by RhoA and lysophosphatidic acid. Exp. Cell Res. 1998, 245, 252-262. [CrossRef] [PubMed] 
186. Defize, L.H.; Boonstra, J.; Meisenhelder, J.; Kruijer, W.; Tertoolen, L.G.; Tilly, B.C.; Hunter, T.; van Bergen en Henegouwen, P.M.; Moolenaar, W.H.; de Laat, S.W. Signal transduction by epidermal growth factor occurs through the subclass of high affinity receptors. J. Cell Biol. 1989, 109, 2495-2507. [CrossRef] [PubMed]

187. Singh, A.V.; Raymond, M.; Pace, F.; Certo, A.; Zuidema, J.M.; McKay, C.A.; Gilbert, R.J.; Lu, X.L.; Wan, L.Q. Astrocytes increase ATP exocytosis mediated calcium signaling in response to microgroove structures. Sci. Rep. 2015, 5, 7847. [CrossRef]

188. Takenaga, K.; Kozlova, E.N. Role of intracellular S100A4 for migration of rat astrocytes. Glia 2006, 53, 313-321. [CrossRef]

189. Lagos-Cabre, R.; Burgos-Bravo, F.; Avalos, A.M.; Leyton, L. Connexins in Astrocyte Migration. Front. Pharmacol. 2019, 10, 1546. [CrossRef]

190. Avalos, A.M.; Arthur, W.T.; Schneider, P.; Quest, A.F.; Burridge, K.; Leyton, L. Aggregation of integrins and RhoA activation are required for Thy-1-induced morphological changes in astrocytes. J. Biol. Chem. 2004, 279, 39139-39145. [CrossRef]

191. Sofroniew, M.V.; Vinters, H.V. Astrocytes: Biology and pathology. Acta Neuropathol. 2010, 119, 7-35. [CrossRef] [PubMed]

192. Sofroniew, M.V. Molecular dissection of reactive astrogliosis and glial scar formation. Trends Neurosci. 2009, 32, 638-647. [CrossRef]

193. Goldshmit, Y.; Munro, K.; Leong, S.Y.; Pebay, A.; Turnley, A.M. LPA receptor expression in the central nervous system in health and following injury. Cell Tissue Res. 2010, 341, 23-32. [CrossRef] [PubMed]

194. Cervera, P.; Tirard, M.; Barron, S.; Allard, J.; Trottier, S.; Lacombe, J.; Daumas-Duport, C.; Sokoloff, P. Immunohistological localization of the myelinating cell-specific receptor LP(A1). Glia 2002, 38, 126-136. [CrossRef]

195. Shano, S.; Moriyama, R.; Chun, J.; Fukushima, N. Lysophosphatidic acid stimulates astrocyte proliferation through LPA1. Neurochem. Int. 2008, 52, 216-220. [CrossRef] [PubMed]

196. Sato, K.; Horiuchi, Y.; Jin, Y.; Malchinkhuu, E.; Komachi, M.; Kondo, T.; Okajima, F. Unmasking of LPA1 receptor-mediated migration response to lysophosphatidic acid by interleukin-1beta-induced attenuation of Rho signaling pathways in rat astrocytes. J. Neurochem. 2011, 117, 164-174. [CrossRef] [PubMed]

197. Olianas, M.C.; Dedoni, S.; Onali, P. LPA1 Mediates Antidepressant-Induced ERK1/2 Signaling and Protection from Oxidative Stress in Glial Cells. J. Pharmacol. Exp. Ther. 2016, 359, 340-353. [CrossRef]

198. Ueda, H.; Neyama, H.; Nagai, J.; Matsushita, Y.; Tsukahara, T.; Tsukahara, R. Involvement of lysophosphatidic acid-induced astrocyte activation underlying the maintenance of partial sciatic nerve injury-induced neuropathic pain. Pain 2018, 159, 2170-2178. [CrossRef]

199. Spohr, T.C.; Choi, J.W.; Gardell, S.E.; Herr, D.R.; Rehen, S.K.; Gomes, F.C.; Chun, J. Lysophosphatidic acid receptor-dependent secondary effects via astrocytes promote neuronal differentiation. J. Biol. Chem. 2008, 283, 7470-7479. [CrossRef]

200. Sapkota, A.; Park, S.J.; Choi, J.W. Receptor for Advanced Glycation End Products Is Involved in LPA5-Mediated Brain Damage after a Transient Ischemic Stroke. Life 2021, 11, 80. [CrossRef] 